Centro de Excelência em Turismo

\title{
A DISCIPLINA DE ADMINISTRAÇÃO APLICADA À FORMAÇÃO DO BACHAREL EM TURISMO
}

\author{
Antonio Henrique Braga
}

\section{Orientador: Prof ${ }^{a}$ MsC. Sandra Vivacqua V. Tiesenhausen}

Monografia apresentada ao Centro de Excelência em Turismo da Universidade de Brasília como requisito parcial para a obtenção do Certificado de Especialista em Docência e Pesquisa.

Brasília, DF, janeiro de 2004 
BRAGA, Antonio Henrique.

A Disciplina Administração de Administração Aplicada à Formação do Bacharel em Turismo. Goiânia - GO, 2003, 88p.

Monografia de Especialização em Pesquisa e Docência em Turismo e Hospitalidade.

1. Diretrizes Curriculares

2. Turismo

3. Conteúdos Programáticos

4. Referências Bibliográficas 


\begin{abstract}
UNIVERSIDADE DE BRASÍLIA
Centro de Excelência em Turismo

Curso de Especialização em Docência e Pesquisa em Turismo e Hospitalidade
\end{abstract}

\title{
A DISCIPLINA DE ADMINISTRAÇÃO APLICADA À FORMAÇÃO DO BACHAREL EM TURISMO
}

Antonio Henrique Braga

Banca Examinadora

Orientador: Prof ${ }^{a}$ MsC. Sandra Vivacqua V. Tiesenhausen

Membro:

Membro:

Brasília, DF, 05 de janeiro de 2004 


\section{ANTONIO HENRIQUE BRAGA}

\section{A DISCIPLINA DE ADMINISTRAÇÃO APLICADA À FORMAÇÃO DO BACHAREL EM TURISMO}

Comissão Avaliadora

Orientador: Prof ${ }^{a}$ MsC. Sandra Vivacqua V. Tiesenhausen

Membro:

Membro:

Brasília, DF, 05 de janeiro de 2004 
Dedico este trabalho aos meus filhos, Isabela, João Henrique e Tamires, os quais foram privados do meu convívio familiar durante vários finais de semana e muitas horas de estudo. E por entenderem que este curso seria um marco importante na minha formação pessoal e profissional.

Dedico, também, à minha esposa Nilda Freitas, grande incentivadora e responsável pela minha participação no curso. 
Agradeço a Deus, pela proteção recebida em todas as viagens a Brasília e por nos ter dado esta grande oportunidade de vida.

Agradeço a duas pessoas especiais, minha irmã Maria das Graças e seu esposo Durval Manzi, por ter viabilizado todo o apoio necessário à nossa hospedagem e descanso em sua residência. 
A única maneira de aprender a pesquisar é fazendo uma pesquisa.

Outros meios, porém, podem ajudar.

Roberto Jarry Richardson 
RESUMO

Esta monografia tem como finalidade analisar os conteúdos programáticos da disciplina Administração Aplicada aos Cursos de Bacharel em Turismo ministrados em Brasília e nos estados de Goiás e Mato Grosso. Verifica se as IES estão acatando as orientações emanadas pelas Diretrizes Curriculares do Ministério da Educação para os cursos de graduação em Turismo; bem como verifica se o referencial bibliográfico adotado pelas IES é concernente à "atividade" turística, ou seja, se as mesmas fazem o link com o turismo. De posse das ementas e programas dos cursos, tabulou-se os conteúdos programáticos e as referências bibliográficas básicas e complementares, verificando as coincidências, os percentuais de participação e o comportamento de cada IES, subsidiando os resultados obtidos pela pesquisa. Visualiza uma panorâmica da oferta de IES da Região Centro-Oeste referente à matéria Administração Aplicada ao Turismo (existente em 2003), no período acadêmico de transição entre dois modelos de organização e flexibilização curricular.

Palavras chaves: turismo - investigação - conteúdos programáticos. 


\section{RESUMEN}

Esta monografía tiene como finalidad analizar los contenidos programáticos de la asignatura Administración Aplicada a los Cursos de Licenciatura en Turismo impartidos en Brasilia (DF) y en los estados de Goiás y Mato Grosso. Se verifica si las Instituciones de Enseñanza Superior (IES) están acatando las orientaciones emanadas por las Directrices Curriculares del Ministerio de la Educación para los Cursos de Graduación en Turismo; se comprueba también si el referencial bibliográfico adoptado por las IES es concerniente a la "actividad" turística, o sea, si las IES se acoplan a la realidad y a las necesidades del mercado del turismo. A partir de las definiciones generales de las asignaturas y de los programas de los cursos, se tabularon los contenidos programáticos y las referencias bibliográficas básicas y complementarias, verificándose las coincidencias, los porcentuales de participación y el comportamiento de cada IES, subsidiando con ello los resultados obtenidos por la investigación. Se visualiza un panorama de la oferta de IES de la Región Centro-Oeste referente a la asignatura Administración Aplicada al Turismo (existente en 2003), en el periodo académico de transición entre dos modelos de organización y flexibilización curricular.

Palabras clave: turismo - investigación - contenidos programáticos. 


\section{SUMÁRIO}

1- Introdução

2 - Panorâmica educativo-institucional da legislação vigente (das normas legais)

2.1 - Dos Cursos de Graduação no sistema educacional

2.1.1 - Diretrizes Bases da Educação ...................................................16

2.1.2 - Diretrizes Curriculares dos cursos de graduação ............................17

2.1.3 - Plano Nacional de Educação .................................................. 19

2.1.4 - Orientação para as Diretrizes Curriculares dos cursos de graduação

2.1.5 - Diretrizes Curriculares dos cursos de graduação em Turismo...........20

2.1.5.1 - Perfil Desejado do Formando...........................................22

2.1.5.2 - Competências e Habilidades ..................................................22

2.1.5.3 - Conteúdos Curriculares......................................................24

2.2 - Dos cursos de formação inicial em Turismo ...................................... 24

2.2.1 - Antecedentes: Currículos mínimos ..........................................25

2.2.2 - Proposta de currículo mínimo III ENBETUR .................................26

2.2.3 - Proposta de currículo mínimo da EMBRATUR .............................26

2.2.4 - Proposta de currículo mínimo da ABBTUR ..................................28

2.2.5 - Proposta de currículo mínimo da ABBTUR e ABDETH ....................29

3 - Descrição da Metodologia da Pesquisa .................................................... 32

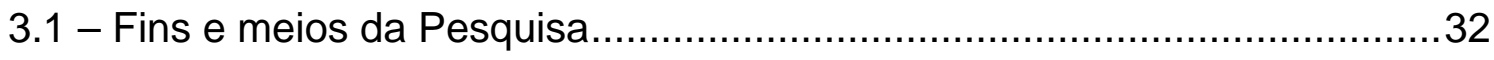

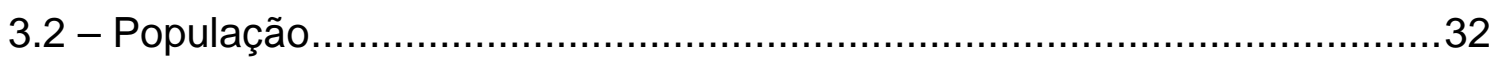

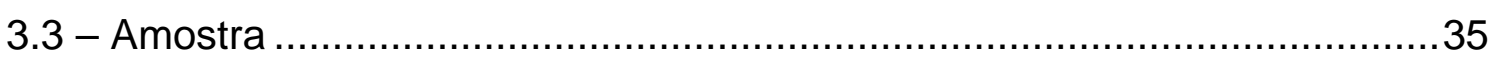

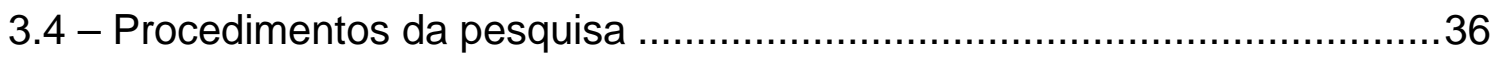

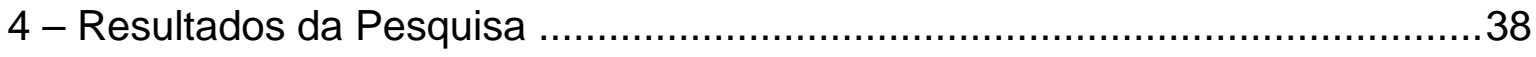

4.1 - Tabulação dos conteúdos programáticos .............................................. 38

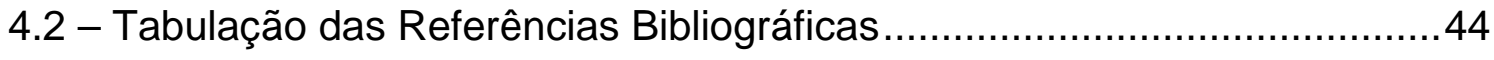

5 - Discussão dos resultados da Pesquisa.............................................54

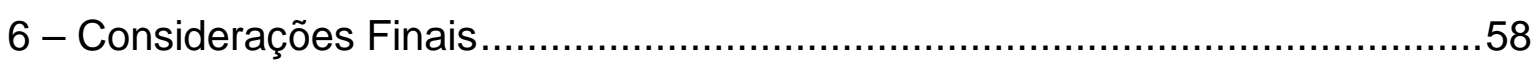

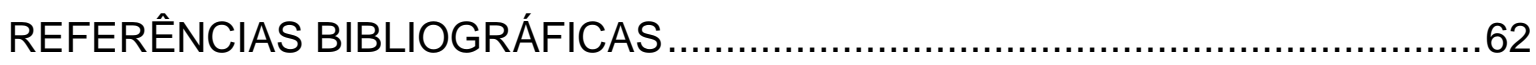

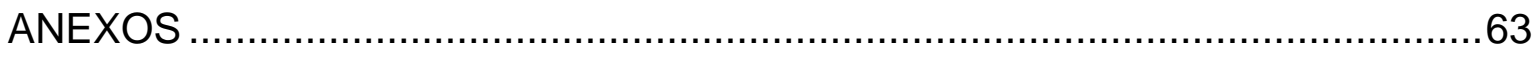

ANEXO 1 - Ementa da Faculdades Objetivo e Universidade Paulista .............64 
ANEXO 2 - Ementa da Faculdade Alves Faria ....................................... 72

ANEXO 3 - Ementa da Faculdade Cambury........................................... 75

ANEXO 4 - Ementa da Faculdade Anhanguera....................................... 77

ANEXO 5 - Ementa do Instituto de Ensino Superior de Brasília .......................79

ANEXO 6 - Ementa da Faculdade Lions ............................................. 83

ANEXO 7 - Ementa do Instituto de Ensino Superior de Cuiabá......................87

ANEXO 7 - Ementa do Instituto de Ensino Superior de Cuiabá.......................87 


\section{Lista de Gráficos}

Gráfico 1: Quantidade de conteúdo programático por IES ..............................42

Gráfico 2: Quantidade de vezes que o conteúdo foi adotado pelas IES ..............43

Gráfico 3: Quantidade de referência bibliográfica básica e complementar ..........51 


\section{Lista de Quadros}

Quadro 1: IES que ministram cursos para a atividade turística.........................33

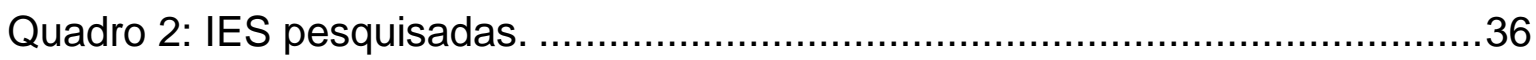




\section{Lista de Tabelas}

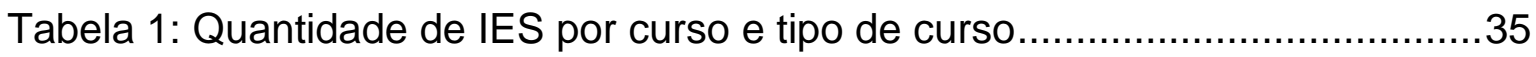

Tabela 2: Tabulação dos conteúdos programáticos.....................................38

Tabela 3: Quantidade de conteúdo programático por IES. ..............................41

Tabela 4: Totalização de conteúdos programáticos comuns às IES ...................42

Tabela 5: Agrupamento dos conteúdos programáticos por assuntos ou títulos....43

Tabela 6: Tabulação das referências bibliográficas básicas. ............................44

Tabela 7: Tabulação das referências bibliográficas complementares..................47

Tabela 8: Dados sintéticos das referências bibliográficas................................51

Tabela 9: Referências bibliográficas básicas comuns as IES. .........................52

Tabela 10: Referências bibliográficas complementares comuns as IES..............52

Tabela 11: Referências bibliográficas básicas que fazem o link com o turismo....52

Tabela 12: Referências bibliográficas complementares que fazem o link com o

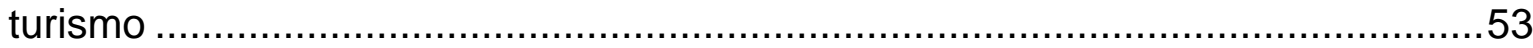


1- Introdução

Este trabalho tem como tema a Administração Aplicada ao Turismo. No primeiro momento pode-se argüir: Do que ela se trata? Pois, o tema tende a se tornar genérico caso permaneça a aplicabilidade linear das técnicas de Administração aos ainda incipientes estudos acadêmicos realizados na área de Turismo. Trata-se assim de tema complexo, pois cria interfaces entre teorias da Administração e os conteúdos diversificados inerentes ao Turismo.

Concordando com essa visão, o pesquisador dispõe-se a explorá-lo mais com o intuito de entendê-lo e justificar a sua execução.

A ciência da Administração desenvolveu-se desde os primórdios da civilização e historiadores comprovaram que ela sempre esteve presente em todas as eras da formação do conhecimento administrativo. Hoje não é diferente; ou até melhor, a Administração eficaz se configura como vantagem competitiva no mundo dos negócios.

Para a atividade turística ela também é imprescindível, pois, além de todos os conhecimentos que a atividade turística exige, precisa-se dos conhecimentos, técnicas, funções, métodos que a administração desenvolveu em outros setores profissionais. No curso de turismo, a disciplina Administração é matéria integradora, participa e facilita a multidisciplinaridade, disponibilizando aos discentes conhecimentos importantes para o seu desenvolvimento profissional.

Analisando as ementas de várias Instituições de Ensino, causou espanto a diversidade de conteúdos programáticos e de referencial teórico básico e complementar adotados, principalmente por não serem relacionados para a atividade turística.

Em um momento em que verificamos um grande crescimento da oferta de cursos de turismo, foi despertada a curiosidade de pesquisar mais sobre 0 assunto, principalmente porque havia uma incógnita sem resposta: como ministrar a disciplina sem referencial teórico que cumpra os conteúdos e que sejam transferíveis e que possam estabelecer o link com o turismo.

Com a realização da pesquisa, o pesquisador entende que haverá possibilidade de estudar, analisar, comparar os diversos conteúdos programáticos da disciplina, adotados por várias IES, além de possibilitar o estudo aprofundado 
das regulamentações sobre o currículo ou diretrizes curriculares do curso. Após a análise crítica dos resultados, será possível produzir uma ementa mais orgânica, condensando todos os conteúdos por assunto, contemplando as necessidades dos diversos cursos; material este que poderá ser utilizado, no futuro, para a produção de um referencial teórico para a disciplina, fazendo a tradução e o link com a atividade turística.

Em contrapartida, a idéia de que o que importa é o desenvolvimento de competências produtivas, freqüentemente faz esquecer que estas não podem se exercer senão a partir de materiais informativos, pois não se exercem em abstrato. Ou seja, não são competências meramente psicológicas, em seguida, meramente "aplicáveis" a qualquer circunstância, mas são, desde o início, sociais, realizando-se sobre materiais do mundo (natural, social e simbólico) - isto é, sobre e com informações.

Nos capítulos que se seguem as considerações e propostas, freqüentemente levantadas durante minha longa experiência profissional, mantêm o foco na convicção de que a matéria Administração tem função integradora nos Cursos de Turismo e que seus conteúdos e práticas são imprescindíveis no processo formativo do Turismólogo.

O trabalho inicia-se pela busca de referencial teórico pertinente, por meio de pesquisa bibliográfica; pesquisou-se para verificar a população de IES que ministram o curso de Bacharel em Turismo, base para a definição da amostra a ser pesquisada mediante análise das ementas e programas da disciplina Administração Aplicada ao Turismo. Em seguida, os dados foram tabulados e apresentados em tabelas e quadros, os quais subsidiaram as análises e os comentários sobre os resultados obtidos. 
2 - Panorâmica educativo-institucional da legislação vigente (das normas legais)

2.1 - Dos Cursos de Graduação no sistema educacional

\subsection{1 - Diretrizes Bases da Educação}

As Diretrizes Bases da Educação Nacional foram estabelecidas pela Lei $\mathrm{n}^{\circ}$ 9.394 de 20 de dezembro de 1996 (LDB/96), a qual tem como objetivo disciplinar a educação escolar, que se desenvolve, predominantemente, por meio do ensino em instituições próprias.

A LDB/96 garante, através do inciso IX do art. $4^{\circ}$, que o ensino deve ter padrões mínimos de qualidade, através de controles em variedade, quantidade mínima por aluno de insumos indispensáveis ao desenvolvimento do processo de ensino-aprendizagem.

A Lei autoriza a iniciativa privada proporcionar ensino, desde que atendidas as normas gerais da educação e do respectivo sistema de ensino; deve possuir autorização de funcionamento e ter sido avaliada qualitativamente pelo poder público, conforme define 0 art. $7^{\circ}$ e seus incisos.

A Lei definiu como competência da União, Estados e Municípios, baixar normas gerais sobre cursos de graduação e pós-graduação, autorizar, reconhecer, credenciar, supervisionar e avaliar, respectivamente, os cursos das instituições de educação superior e os estabelecimentos do seu sistema de ensino, consoante ao art. $9^{\circ}$ incisos VII e IX.

Quanto à Educação Superior, a LDB/96 previu, através do seu art. 43 que a educação superior tem por finalidade:

- estimular a criação cultural e o desenvolvimento do espírito científico e do pensamento reflexivo;

- formar diplomados nas diferentes áreas de conhecimento, aptos para a inserção em setores profissionais e para a participação no desenvolvimento da sociedade brasileira, e colaborar na sua formação contínua; 
- incentivar o trabalho de pesquisa e investigação científica, visando o desenvolvimento da ciência e da tecnologia e da criação e difusão da cultura, e, desse modo, desenvolver o entendimento do homem e do meio em que vive;

- promover a divulgação de conhecimentos culturais, científicos e técnicos que constituem patrimônio da humanidade e comunicar o saber através do ensino, de publicações ou de outras formas de comunicação;

- suscitar o desejo permanente de aperfeiçoamento cultural e profissional e possibilitar a correspondente concretização, integrando os conhecimentos que vão sendo adquiridos numa estrutura intelectual sistematizadora do conhecimento de cada geração;

- estimular o conhecimento dos problemas do mundo presente, em particular os nacionais e regionais, prestar serviços especializados à comunidade e estabelecer com esta uma relação de reciprocidade;

- promover a extensão, aberta à participação da população, visando à difusão das conquistas e benefícios resultantes da criação cultural e da pesquisa científica e tecnológica geradas na instituição.

Podemos assim constatar que a LDB/96 definiu que a educação superior deve preparar o indivíduo para a inserção profissional e para a participação no desenvolvimento da sociedade brasileira, estabelecendo um conjunto de princípios educativos que devem reger a dinâmica de uma formação de cunho participativa e socialmente referenciada. O pesquisador deu ênfase à metas que apontam um profissional estimulado a exercitar o pensamento reflexivo e incentivado, tanto em nível nacional quanto global. Deve ser incentivado para o trabalho de pesquisa e investigação científica com a possibilidade de produção do conhecimento científico.

\subsection{2 - Diretrizes Curriculares dos cursos de graduação}

Com o propósito de responder às demandas político-sociais de uma sociedade em desenvolvimento e à luz dos pressupostos filosóficos da LDB/96, o Conselho Nacional de Educação emitiu o Parecer CNE/CES 776/97 o qual as define como sendo as orientações para a elaboração dos currículos que devem 
ser necessariamente respeitadas por todas as instituições de ensino superior, assegurando flexibilidade e qualidade na formação oferecida aos estudantes. Deve ainda contemplar elementos de fundamentação essencial em cada área do conhecimento, campo do saber ou profissão, visando promover no estudante a capacidade de desenvolvimento intelectual e profissional autônomo e permanente de forma a proporcionar uma sólida formação básica, preparando o futuro graduado para enfrentar os desafios das rápidas transformações da sociedade, do mercado de trabalho e das condições de exercício profissional.

Neste sentido, o Parecer definiu os seguintes princípios:

1 - Assegurar às instituições de ensino superior ampla liberdade na composição da carga horária a ser cumprida para a integralização dos currículos, assim como na especificação das unidades de estudos a serem ministradas;

2 - Indicar os tópicos ou campos de estudo e demais experiências de ensinoaprendizagem que comporão os currículos, evitando ao máximo a fixação de conteúdos específicas com cargas horárias pré-determinadas, as quais poderão exceder $50 \%$ da carga horária total dos cursos;

3 - Evitar o prolongamento desnecessário da duração dos cursos de graduação;

4 - Incentivar uma sólida formação geral, necessária para que o futuro graduado possa vir a superar os desafios de renovadas condições de exercício profissional e de produção do conhecimento, permitindo variados tipos de formação e habilidades diferenciadas em um mesmo programa;

5 - Estimular práticas de estudo independente, visando uma progressiva autonomia profissional e intelectual do aluno;

6 - Encorajar o reconhecimento de conhecimentos, habilidades e competências adquiridas fora do ambiente escolar, inclusive as que se referiram à experiência profissional julgada relevante para a área de formação considerada; 
7 - Fortalecer a articulação da teoria com a prática, valorizando a pesquisa individual e coletiva, assim como os estágios e a participação em atividades de extensão;

8 - Incluir orientações para a condução de avaliações periódicas que utilizem instrumentos variados e sirvam para informar a docentes e a discentes acerca do desenvolvimento das atividades didáticas.

\subsection{3 - Plano Nacional de Educação}

O Plano Nacional de Educação, Lei 10.172 de janeiro de 2001, define nos seus objetivos e metas: “... 11. Estabelecer, em nível nacional, diretrizes curriculares que assegurem a necessária flexibilidade e diversidade nos programas oferecidos pelas diferentes instituições de ensino superior, de forma a melhor atender às necessidades diferenciais de suas clientelas e às peculiaridades das regiões nas quais se inserem...".

2.1.4 - Orientação para as Diretrizes Curriculares dos cursos de graduação

O Parecer CNE/CES 583/2001 de 04/04/2001 corroborou os princípios das Diretrizes Curriculares dos cursos de graduação definidos pelo Parecer CNE/CES $776 / 97$.

Definiu, ainda, que as Diretrizes devem contemplar:

a - Perfil do formando/egresso/profissional - conforme o curso o projeto pedagógico deverá orientar o currículo para um perfil profissional desejado;

b - Competências/habilidades/atitudes;

c - Habilidades e ênfases;

d - Conteúdos curriculares;

e - Organização do curso;

f - Estágios e Atividades Complementares;

g - Acompanhamento e Avaliação. 
2.1.5 - Diretrizes Curriculares dos cursos de graduação em Turismo

Através do Parecer CNE/CES 146/2002, de 03/04/2002, o Conselho Nacional de Educação definiu as Diretrizes Curriculares Nacionais dos cursos de graduação em Turismo e Hotelaria.

$\mathrm{Na}$ parte inicial do parecer, os relatores apresentaram uma análise importante para a fundamentação teórica da pesquisa, conforme transcrito abaixo:

1) enquanto os Currículos Mínimos estavam comprometidos com a emissão de um diploma para o exercício profissional, as Diretrizes Curriculares Nacionais não se vinculam a diploma e a exercício profissional, pois os diplomas, de acordo com o art. 48 da LDB, se constituem prova, válida nacionalmente, da formação recebida por seus titulares;

2) enquanto os Currículos Mínimos encerravam a concepção do exercício do profissional, cujo desempenho resultaria especialmente das disciplinas ou matérias profissionalizantes, enfeixadas em uma grade curricular, com os mínimos obrigatórios fixados em uma resolução por curso, as Diretrizes Curriculares Nacionais concebem a formação de nível superior como um processo contínuo, autônomo e permanente, com uma sólida formação básica e uma formação profissional fundamentada na competência teóricoprática, de acordo com o perfil de um formando adaptável às novas e emergentes demandas;

3) enquanto os Currículos Mínimos inibiam a inovação e a criatividade das instituições, que não detinham liberdade para reformulações naquilo que estava, por Resolução do CFE, estabelecido nacionalmente como componentes curriculares e até com detalhamento de conteúdos obrigatórios, as Diretrizes Curriculares Nacionais ensejam a flexibilização curricular e a liberdade de as instituições elaborarem seus projetos pedagógicos para cada curso segundo uma adequação às demandas sociais e do meio e aos avanços científicos e tecnológicos, conferindo-Ihes uma maior autonomia na definição dos currículos plenos dos seus cursos; 
4) enquanto os Currículos Mínimos muitas vezes atuaram como instrumento de transmissão de conhecimentos e de informações, inclusive prevalecendo interesses corporativos responsáveis por obstáculos no ingresso no mercado de trabalho e por desnecessária ampliação ou prorrogação na duração do curso, as Diretrizes Curriculares Nacionais orientam-se na direção de uma sólida formação básica, preparando o futuro graduado para enfrentar os desafios das rápidas transformações da sociedade, do mercado de trabalho e das condições de exercício profissional;

5) enquanto o Currículo Mínimo profissional pretendia, como produto, um profissional "preparado", as Diretrizes Curriculares Nacionais pretendem preparar um profissional adaptável a situações novas e emergentes;

6) enquanto os Currículos Mínimos, comuns e obrigatórios em diferentes instituições, se propuseram mensurar desempenhos profissionais no final do curso, as Diretrizes Curriculares Nacionais se propõem ser um referencial para a formação de um profissional em permanente preparação, visando uma progressiva autonomia profissional e intelectual do aluno, apto a superar os desafios de renovadas condições de exercício profissional e de produção de conhecimento;

7) enquanto os Currículos Mínimos eram fixados para uma determinada habilitação profissional, assegurando direitos para o exercício de uma profissão regulamentada, as Diretrizes Curriculares Nacionais devem ensejar variados tipos de formação e habilitações diferenciadas em um mesmo programa.

Desta forma, a partir de toda a legislação acima referenciada, foram estabelecidas as Diretrizes Curriculares Nacionais dos cursos de Turismo, segundo a respectiva área de conhecimento, observando-se os paradigmas, níveis de abordagem, perfil do formando, competências e habilidades, habilitações, conteúdos ou tópicos de estudos, duração dos cursos, atividades práticas e complementares, aproveitamento de habilidades e competências extracurriculares, interação com a avaliação institucional como eixo balizador para o credenciamento e avaliação da instituição, para a autorização e reconhecimento 
de cursos, bem como suas renovações, adotados indicadores de qualidade, sem prejuízo de outros aportes considerados necessários.

\subsubsection{1 - Perfil Desejado do Formando}

Quanto ao perfil desejado, o curso de graduação em Turismo deverá oportunizar a formação de um profissional apto a atuar em mercados altamente competitivos e em constante transformação, cujas opções possuem um impacto profundo na vida social, econômica e no meio ambiente, exigindo uma formação ao mesmo tempo generalista, no sentido tanto do conhecimento geral, das ciências humanas, sociais, políticas, econômicas como também de uma formação especializada, constituída de conhecimentos específicos, sobretudo nas áreas culturais, históricas, ambientais, antropológicas, de Inventário do Patrimônio Histórico e Cultural, bem como o agenciamento, organização e gerenciamento de eventos e a administração do fluxo turístico.

\subsubsection{2 - Competências e Habilidades}

O curso de graduação em Turismo deve possibilitar formação profissional que revele, pelo menos, as seguintes competências e habilidades:

- $\quad$ compreensão das políticas nacionais e regionais sobre turismo;

- $\quad$ utilização de metodologia adequada para o planejamento das ações turísticas, abrangendo projetos, planos e programas, com os eventos locais, regionais, nacionais e internacionais;

- positiva contribuição na elaboração dos planos municipais e estaduais de turismo;

- domínio das técnicas indispensáveis ao planejamento e à operacionalização do Inventário Turístico, detectando áreas de novos negócios e de novos campos turísticos e de permutas culturais;

- domínio e técnicas de planejamento e operacionalização de estudos de viabilidade econômico-financeira para os empreendimentos e projetos turísticos; 
- $\quad$ adequada aplicação da legislação pertinente;

- planejamento e execução de projetos e programas estratégicos relacionados com empreendimentos turísticos e seu gerenciamento;

- $\quad$ intervenção positiva no mercado turístico, com sua inserção em espaços novos, emergentes ou inventariados;

- classificação, sobre critérios prévios e adequados, de estabelecimentos prestadores de serviços turísticos, incluindo meios de hospedagens, transportadoras, agências de turismo, empresas promotoras de eventos e de outras áreas, postas com segurança à disposição do mercado turístico e de sua expansão;

- domínio de técnicas relacionadas com a seleção e avaliação de informações geográficas, históricas, artísticas, esportivas, recreativas e de entretenimento, folclóricas, artesanais, gastronômicas, religiosas, políticas e outros traços culturais, como diversas formas de manifestação da comunidade humana;

- domínio de métodos e técnicas indispensáveis ao estudo dos diferentes mercados turísticos, identificando os prioritários, inclusive para efeito de oferta adequada a cada perfil do turista;

- comunicação interpessoal, intercultural, expressão correta e precisa sobre aspectos técnicos específicos e da interpretação da realidade das organizações e dos traços culturais de cada comunidade ou segmento social;

- utilização de recursos turísticos como forma de educar, orientar, assessorar, planejar e administrar a satisfação das necessidades dos turistas e das empresas, instituições públicas ou privadas, e dos demais segmentos populacionais;

- domínio de diferentes idiomas que ensejem a satisfação do turista em sua intervenção nos traços culturais de uma comunidade ainda não conhecida;

- habilidade no manejo com a informática e com outros recursos tecnológicos;

- $\quad$ integração nas ações de equipes interdisciplinares e multidisciplinares interagindo criativamente nos diferentes contextos organizacionais e sociais;

- compreensão da complexidade do mundo globalizado e das sociedades pós-industriais, onde os setores de turismo e entretenimento encontram ambientes propícios para se desenvolverem; 
- profunda vivência e conhecimento das relações humanas, de relações públicas, das articulações interpessoais, com posturas estratégicas para o êxito de qualquer evento turístico;

- conhecimentos específicos e adequado desempenho técnico-profissional, com humanismo, simplicidade, segurança, empatia e ética.

\subsubsection{3 - Conteúdos Curriculares}

Os cursos de graduação em Turismo deverão contemplar, em seus projetos pedagógicos e em sua organização curricular, conteúdos que atendam aos seguintes eixos interligados de formação:

I - Conteúdos Básicos: estudos relacionados com os aspectos Sociológicos, Antropológicos, Históricos, Filosóficos, Geográficos, Culturais e Artísticos, que conformam as sociedades e suas diferentes culturas;

II - Conteúdos Específicos: estudos relacionados com a Teoria Geral do Turismo, Teoria da Informação e da Comunicação, estabelecendo ainda as relações do Turismo com a Administração, o Direito, a Economia, a Estatística e a Contabilidade, além do domínio de, pelo menos, uma língua estrangeira;

III - Conteúdos Teórico-Práticos: estudos localizados nos respectivos espaços de fluxo turístico, compreendendo visitas técnicas, inventário turístico, laboratórios de aprendizagem e de estágios.

2.2 - Dos cursos de formação inicial em Turismo

Nesta etapa do referencial teórico, será feito um breve histórico do desenvolvimento dos dois modelos curriculares de formação em nível superior para o profissional de Turismo, abrangendo do "currículo mínimo" às Diretrizes Curriculares, período que perdurou por quase 21 anos (1981 - 2002). 
2.2.1 - Antecedentes: Currículos mínimos

Ainda na vigência da lei 5.672/71, a antiga LDB (1971 - 1996), os Cursos de Bacharelado em Turismo, ainda que em número reduzido, mereceram a formulação, pelo Ministério da Educação, da Resolução MEC S/N de 28 de fevereiro de 1971.

Esta Resolução apenas definiu as matérias e atividades mínimas a serem ministradas ou aplicadas no curso de turismo, através do Art. $2^{\circ}$, conforme relatada abaixo:

a) Matérias:

- Sociologia;

- História do Brasil;

- Geografia do Brasil;

- História da Cultura;

- Estudos Brasileiros;

- Introdução à Administração;

- Noções de Direito;

- Técnica Publicitária;

- Planejamento e Organização do Turismo.

- Estágio em entidades oficiais e privadas de Turismo e Hotelaria.

No art. $6^{\circ}$, a mesma resolução definiu que a carga horária mínima deverá ser de pelo menos 1.600 horas.

Paralelamente à institucionalização deste novo curso, coube às entidades vinculadas ao Turismo promover debates e introduzir no âmbito dos cursos de Graduação, as diferentes proposta de formação em nível superior dessa profissão emergente. Observamos ainda que as formulações dessas entidades, embora utilizem o modelo anterior de "Currículos Mínimos", já enfatizam a importância de uma formação profissional de caráter mais abrangente que àquela restrita ao campo da Administração. Destacam-se: 
2.2.2 - Proposta de currículo mínimo III ENBETUR

Em 1981, durante a realização do III ENBETUR - Porto Alegre - RS, através de uma comissão criada para discutir o assunto, apresentou-se ao Conselho Federal de Educação a seguinte proposta de currículo mínimo:

a) Matérias do Currículo Mínimo

I. Sociologia;

II. História;

III. Geografia;

IV. Administração;

V. Direito;

VI. Ciências e Técnicas da Comunicação;

VII. Planejamento e Organização do Turismo;

VIII. Estatística;

IX. Metodologia Científica;

X. Economia;

XI. Psicologia;

XII. Antropologia;

XIII. Contabilidade.

b) Habilitações

I. Administração de Empresas Turísticas;

II. Planejamento do Turismo;

III. Animação Turística.

2.2.3 - Proposta de currículo mínimo da EMBRATUR

A Comissão criada em 1981 pelo III ENBETUR solicitou parecer da EMBRATUR sobre a proposta de currículo mínimo elabora naquele evento. A 
EMBRATUR, por sua vez consultou as partes interessadas no assunto, ou seja, a comunidade acadêmica e empresarial, consolidando as visões de cada setor e propondo algumas alterações importantes na proposta apresentada, formatando uma nova visão com habilitações optativas, conforme apresentado abaixo:

a) Matérias Básicas

I. Matemática;

II. Estatística;

III. Contabilidade;

IV. Teoria Econômica;

V. Metodologia Científica;

VI. Planejamento e Organização do Turismo;

VII. Legislação Aplicada;

VIII. Mercadologia;

IX. Psicologia.

b) Habilitações Alternativas

a. 1ª Opção - Hotelaria

i. Organização Hoteleira e Técnicas Operacionais;

ii. Administração Hoteleira;

iii. Administração Financeira e Orçamento;

iv. Mercadologia Aplicada;

v. Prática - Estágio.

b. 2a Opção - Agenciamento e Transporte

i. Produção e Organização de Serviços Turísticos;

ii. Administração Aplicada;

iii. Administração Financeira e Orçamento;

iv. Mercadologia;

v. Prática-Estágio.

c. $3^{\mathrm{a}}$ Opção - Planejamento

i. Sociologia; 

ii. Organização de Turismo Interno e Externo;
iii. Infra-estrutura Turística;
iv. Equipamento Turístico;
v. Elaboração e Análise de Projetos;
vi. Prática - Estágio.

É importante ressaltar que, nesta proposta, a carga horária mínima do curso passa para 2.700 horas e prática profissional (Estágio) não inferior a 270 horas.

2.2.4 - Proposta de currículo mínimo da ABBTUR

Em 1995, por ocasião do ENBETUR, a ABBTUR/Nacional formulou proposta de um novo currículo mínimo de Turismo, constituído por: tronco comum, ênfases e disciplinas eletivas. Conforme apresentado abaixo:

a) Matérias ou disciplinas tronco
I. Sociologia;
II. História do Brasil;
III. Geografia do Brasil;
IV. História da Cultura;
V. Patrimônio Turístico;
VI. Introdução à Administração;
VII. Noções de Direito;
VIII. Técnicas Publicitárias;
IX. Planejamento e Organização do Turismo.

b) Matérias ou Disciplinas Eletivas
I. Psicologia;
II. Língua Estrangeira;
III. Economia;
IV. Realidade Socioeconômica e Política Regional; 
V. Teoria Geral de Sistemas e Métodos de Pesquisa em Turismo;

VI. Filosofia;

VII. Língua Portuguesa;

VIII. Meio Ambiente;

IX. Relações Humanas.

c) Ênfases sugeridas

I. Agenciamento;

II. Alimentos e Bebidas;

III. Eventos;

IV. Hotelaria e Meios de Hospedagem;

V. Lazer e Recreação;

VI. Planejamento Turístico;

VII. Transportes.

2.2.5 - Proposta de currículo mínimo da ABBTUR e ABDETH

Em 1996 a ABBTUR e ABDETH, após um trabalho conjunto de análise e avaliação curricular do curso de Turismo, elaboraram uma proposta definitiva que contemplasse todas as necessidades de disciplinas para a formação do profissional de turismo, encaminhando-a ao MEC para aprovação, conforme apresentada abaixo:

a) Carga horária mínima: 3.000 horas/aula

b) Tempo mínimo de duração do curso: 4 anos

c) Estrutura curricular:

- Formação básica: $25 \%$ - 750 horas/aula

- Formação Profissional: 45\% - 1.350 horas/aula

- Formação complementar: 20\% - 600 horas/aula

- Estágio: 10\% - 300 horas/aula 
d) Matérias de Formação Básica:

* Sociologia;

* Geografia;

* História;

* Administração;

* Direito;

* Economia;

* Estatística;

* Metodologia científica;

* Psicologia.

e) Matérias de Formação Profissional

* Planejamento e Organização do Turismo;

* Teoria Geral do Turismo (TGT);

* Marketing;

* Eventos;

* Lazer;

* Hospedagem;

* Alimentos e Bebidas (A\&B);

* Agenciamento;

* Transportes;

* Informática;

* Contabilidade;

* Língua Estrangeira.

f) Matérias de Formação Complementar

* Antropologia;

* Língua Portuguesa;

* .Matemática. 
Como ficou evidenciado, a responsabilidade acadêmica das agências formadoras (IES) se torna de vital importância no momento de formalizar e definir seus diferentes currículos plenos.

O presente trabalho continua, pretendendo demonstrar como um dos componentes curriculares - o dos materiais pedagógicos, em especial a bibliografia básica e complementar disponibilizada responde à visão veiculada nas determinações emanadas pela LDB, nas orientações das diretrizes curriculares e no desenvolvimento dos currículos definidos pelo MEC e pelas entidades de classe que atuam na atividade turística. 
3 - Descrição da Metodologia da Pesquisa

3.1 - Fins e meios da Pesquisa

Tendo em vista o problema dessa investigação, ou seja, verificar se os conteúdos programáticos da disciplina de Administração ministrada nos cursos de Turismo estão adequados às exigências e regulamentações emanadas pelas diretrizes curriculares dos Cursos de Graduação em Turismo, além de verificar se o referencial teórico básico e complementar contempla qualitativa e quantitativamente o conteúdo programático da disciplina em estudo, esta pesquisa, quanto aos Fins será uma investigação comparativa.

Comparativa porque será feita a análise de várias ementas e de seus respectivos conteúdos programáticos, verificando-se o grau e a natureza de relacionamento e coincidências dos conteúdos adotados pelas IES pesquisadas, analisando-as à luz da legislação vigente, confirmando ou não a adequação dos mesmos.

Quanto aos Meios esta pesquisa é documental e bibliográfica. Documental porque as ementas em estudo são documentos internos utilizados pelos Coordenadores e Docentes dos cursos.

Ela será eminentemente bibliográfica, tendo em vista que será necessário buscar referencial teórico-metodológico relacionado com o desenvolvimento da legislação que atualmente normatiza os cursos de graduação, bem como a investigação sobre outros trabalhos que versem ou que analisam o currículo do curso de turismo.

\section{2 - População}

Com o objetivo de verificar a quantidade de cursos de graduação em turismo nos estados de Goiás, Mato Grosso e Distrito Federal, realizou-se uma pesquisa nos Sites da EMBRATUR e da ABBTUR, que resultou nas informações apresentadas na Quadro 1. 
Quadro 1: IES que ministram cursos para a atividade turística

\begin{tabular}{|c|c|c|c|c|c|c|c|}
\hline SEQ & IES & CURSO & $\begin{array}{c}\text { TIPO } \\
\text { CURSO }\end{array}$ & ENDEREÇO & ESTADO & CIDADE & SITE \\
\hline 1 & Faculdades Objetivo & Turismo & Graduação & $\begin{array}{l}\text { SGAS Q. } 913 \text { BI.B Cj. } 3 \text { - Asa Su } \\
\text { 70390-130 }\end{array}$ & $\begin{array}{l}\text { Distrito Federal, } \\
\text { Goiânia e Rio } \\
\text { Verde }\end{array}$ & $\begin{array}{l}\text { Brasília e } \\
\text { Goiás }\end{array}$ & $\begin{array}{l}\text { http://www.objetivo- } \\
\text { bsb.com.br } \\
\text { http:/www.objetivo- } \\
\text { goiania.com.br }\end{array}$ \\
\hline 2 & $\begin{array}{l}\text { Centro Universitário } \\
\text { de Brasília - CUB }\end{array}$ & Turismo & Graduação & $\begin{array}{l}\text { EQN 707/907 BI. } 10 \text { - Asa Norte } \\
\text { 70390-130 }\end{array}$ & Distrito Federal & Brasília & http://www.ceub.br \\
\hline 3 & Faculdade CECAP & Turismo & Graduação & $\begin{array}{l}\text { SHIN EQL 9/11, Lt. B - Lago Norte } \\
\text { 71515-205 }\end{array}$ & Distrito Federal & Brasília & http://www.cecap.com.br \\
\hline 5 & $\begin{array}{l}\text { Faculdade da Terra } \\
\text { de Brasília }\end{array}$ & Turismo & Graduação & $\begin{array}{l}\text { Av. Recanto das Emas, Área } \\
\text { Especial, Q. 203, Lote } 32 \\
72610-300\end{array}$ & Distrito Federal & Brasília & http://www.ftp.br \\
\hline 6 & $\begin{array}{l}\text { Faculdade Euro- } \\
\text { Americana }\end{array}$ & Turismo & Graduação & $\begin{array}{l}\text { SCES, Trecho 0, Cj. } 5 \text { - Av. das } \\
\text { Nações } 70200-001\end{array}$ & Distrito Federal & Brasília & $\begin{array}{l}\text { http://www.euroamerican } \\
\text { a.com.br }\end{array}$ \\
\hline 7 & $\begin{array}{l}\text { Faculdades } \\
\text { Caiçaras }\end{array}$ & Turismo & Graduação & $\begin{array}{l}\text { SCDN Lt. M Lj. } 1 \text { - Setor Norte } \\
72705-000\end{array}$ & Distrito Federal & Brasília & $\begin{array}{l}\text { http://www.facbraz.hpg.c } \\
\text { om.br }\end{array}$ \\
\hline 8 & Faculdades Planalto & $\begin{array}{l}\text { Administração } \\
\text { em Hotelaria }\end{array}$ & Graduação & 708/907 Sul 70390-079 & Distrito Federal & Brasília & http://www.iesplan.br \\
\hline 11 & $\begin{array}{l}\text { Faculdades } \\
\text { Integradas da UPIS }\end{array}$ & Turismo & Graduação & $\begin{array}{l}\text { Sep Sul, Eq 712/912, Conj. A, Asa } \\
\text { Sul - CEP: } 70390-125\end{array}$ & Distrito Federal & Brasília & http://www.upis.br \\
\hline 12 & $\begin{array}{l}\text { Centro Federal de } \\
\text { Educação } \\
\text { Tecnológica de } \\
\text { Goiás } \\
\end{array}$ & $\begin{array}{l}\text { Turismo e } \\
\text { Hotelaria }\end{array}$ & Tecnólogo & $\begin{array}{l}\text { Rua 75, } 46 \text { - Centro } \\
\text { 74055-110 }\end{array}$ & Goiás & Goiânia & http://www.cefetgo.br \\
\hline 13 & $\begin{array}{l}\text { Faculdade } \\
\text { Anhanguera de } \\
\text { Ciências Humanas }\end{array}$ & Turismo & Graduação & $\begin{array}{l}\text { Rua Prof Lázaro Costa, } 456 \text { - } \\
\text { Cidade Jardim } 74415-420\end{array}$ & Goiás & Goiânia & http://www.fach.br \\
\hline 14 & Faculdade Cambury & Turismo & Graduação & Av. Fued José Sebba, c/ Rua 24 - & Goiás & Goiânia & http://www.cambury.br \\
\hline
\end{tabular}




\begin{tabular}{|c|c|c|c|c|c|c|c|}
\hline & & & & Qd. A-16, $118474805-100$ & & & \\
\hline 15 & $\begin{array}{l}\text { Faculdade de } \\
\text { Caldas Novas }\end{array}$ & Turismo & Graduação & $\begin{array}{l}\text { Av. Portal do Lago, Q. 9, Lt. 1-28, } \\
\text { Setor Portal do Lago 75690-000 }\end{array}$ & Goiás & $\begin{array}{l}\text { Caldas } \\
\text { Novas }\end{array}$ & $\begin{array}{l}\text { http://www.unicaldas.edu } \\
\text {.br }\end{array}$ \\
\hline 16 & $\begin{array}{l}\text { Faculdade Latino } \\
\text { Americana }\end{array}$ & Turismo & Graduação & $\begin{array}{l}\text { Avenida Universitária } \\
75080-150\end{array}$ & Goiás & Anápolis & \\
\hline 17 & Faculdade Lions & Turismo & Graduação & $\begin{array}{l}\text { Rua Armogaste José da Silveira, } \\
350 \text { - Fama } 74560-550\end{array}$ & Goiás & Goiânia & http://www.unilions.org \\
\hline 18 & Faculdade Padrão & $\begin{array}{l}\text { Administração } \\
\text { em Turismo }\end{array}$ & Graduação & $\begin{array}{l}\text { Avenida Universitária, } 120 \text { - Centro } \\
74360-210\end{array}$ & Goiás & Goiânia & $\begin{array}{l}\text { http://www.faculdadepadr } \\
\text { ao.com.br }\end{array}$ \\
\hline 19 & $\begin{array}{l}\text { Faculdades Alves } \\
\text { Faria }\end{array}$ & Turismo & Graduação & $\begin{array}{l}\text { Av. Perimetral Norte, } 4219 \text { - Vila } \\
\text { João Vaz } 74445-190\end{array}$ & Goiás & Goiânia & http://www.alfa.br \\
\hline 20 & $\begin{array}{l}\text { Universidade } \\
\text { Católica de Goiás }\end{array}$ & $\begin{array}{l}\text { Administração } \\
\text { em Turismo }\end{array}$ & Graduação & $\begin{array}{l}\text { Av. Univercitária } \\
\text { cep:74605010 }\end{array}$ & Goiás & Goiânia & http://www.ucg.br \\
\hline 21 & $\begin{array}{l}\text { Centro Superior de } \\
\text { Rondonópolis }\end{array}$ & Turismo & Graduação & $\begin{array}{l}\text { Av. Ari Coelho, } 829 \\
78705-050\end{array}$ & Mato Grosso & $\begin{array}{l}\text { Rondonóp } \\
\text { olis }\end{array}$ & http://www.cesur.br \\
\hline 22 & $\begin{array}{l}\text { Centro Universiário } \\
\text { de Várzea Grande }\end{array}$ & Turismo & Graduação & $\begin{array}{l}\text { Av. Dom Orlando Chaves, } 2655 \text { - } \\
\text { Cristo Rei } \quad 78118-000\end{array}$ & Mato Grosso & $\begin{array}{l}\text { Várzea } \\
\text { Grande }\end{array}$ & http://www.univag.com.br \\
\hline 23 & $\begin{array}{l}\text { Faculdade } \\
\text { Afirmativo }\end{array}$ & Turismo & Graduação & $\begin{array}{l}\text { Rua Coronel Pimenta Bueno, } 534 \text { - } \\
\text { Bairro Dom Aquino } 78015-380\end{array}$ & Mato Grosso & Cuiabá & $\begin{array}{l}\text { http://www.afirmativo.co } \\
\text { m.br }\end{array}$ \\
\hline 24 & $\begin{array}{l}\text { Faculdade de } \\
\text { Cuiabá }\end{array}$ & Turismo & Graduação & $\begin{array}{l}\text { Av. Dom Aquino, } 319 \text { - Centro } \\
78015-550\end{array}$ & Mato Grosso & Cuiabá & http://www.fauc.com.br \\
\hline 25 & $\begin{array}{l}\text { Faculdade Teles } \\
\text { Pires }\end{array}$ & Turismo & Graduação & $\begin{array}{l}\text { Av. Perimetral Sul, s/n } \\
78510-000\end{array}$ & Mato Grosso & Itaúba & http://www.fatep.edu.br \\
\hline 26 & $\begin{array}{l}\text { Faculdades } \\
\text { Integradas Cândido } \\
\text { Rondon }\end{array}$ & Turismo & Graduação & $\begin{array}{l}\text { Av. Beira Rio, } 3001 \text { - Jardim Europa } \\
78065-780\end{array}$ & Mato Grosso & Cuiabá & http://www.unirondon.br \\
\hline 27 & $\begin{array}{l}\text { Universidade do } \\
\text { Estado de Mato } \\
\text { Grosso }\end{array}$ & Turismo & Graduação & $\begin{array}{l}\text { BR 158, km } 148 \\
78690-000\end{array}$ & Mato Grosso & $\begin{array}{l}\text { Nova } \\
\text { Xavantina }\end{array}$ & http://www.unemat.br \\
\hline
\end{tabular}

Fonte: EMBRATUR E ABBTUR 
Com base no Quadro 1 consolidou-se os dados por curso e por tipo do curso (graduação e tecnólogo), resultando na Tabela 1.

Tabela 1: Quantidade de IES por curso e tipo de curso

\begin{tabular}{|l|l|c|c|}
\hline \multicolumn{1}{|c|}{ Curso } & \multicolumn{1}{c|}{ Tipo } & $\begin{array}{c}\text { Quantidade de } \\
\text { IES }\end{array}$ & $\begin{array}{c}\text { Frequência } \\
\text { relativa }\end{array}$ \\
\hline Turismo & Graduação & 23 & $85,19 \%$ \\
\hline Turismo & Tecnólogo & 1 & $3,70 \%$ \\
\hline Administração em Hotelaria & Graduação & 1 & $3,70 \%$ \\
\hline Administração em Turismo & Graduação & 2 & $7,41 \%$ \\
\hline Total & - & $\mathbf{2 7}$ & $\mathbf{1 0 0 , 0 0 \%}$ \\
\hline
\end{tabular}

Fonte: EMBRATUR e ABBTUR

Observamos que existem 27 IES que ministram cursos voltados para a atividade turística. No entanto, o foco dessa pesquisa é o curso de Bacharel em Turismo, ou seja, curso totalmente voltado para a formação do Turismólogo. Neste sentido, a população a ser estudada é de 23 IES, ou 85,19\% da população.

Para as IES que mantêm mais de um curso de Turismo, caso da Universidade Paulista (Brasília e Goiânia), Faculdades Objetivo (Brasília, Goiânia e Rio Verde) e da Faculdade Cambury (Goiânia e Luziânia), considerou-se apenas como uma IES, tendo em vista que as ementas e conteúdos programáticos são os mesmos o que poderia apresentar um resultado que não expresse a realidade além de conotar tendência na pesquisa.

\section{3 - Amostra}

A partir da população, utilizou-se o critério da acessibilidade, ou seja, as IES estudadas foram aquelas que disponibilizaram as ementas sem restrição. Ementas de outras IES foram solicitadas, porém, não se obteve resposta favorável. Entendemos em parte, pois, trata-se de um documento interno que faz parte do projeto pedagógico da IES, de caráter confidencial e que pode suscitar dúvidas sobre a sua utilização. Lamentamos o fato de não poder contar com todas as IES. 
Mesmo com a dificuldade encontrada entendemos que a amostra de 08 (oito) IES é suficiente para ter uma representação quantitativa e qualitativa das IES que ministram o curso de Bacharel em Turismo na região Centro-Oeste.

Reforçando o nosso entendimento sobre a amostra, Tiboni (2003, p. 21), recomenda que a amostra não deve ser menor que 10\% (dez por cento) do total de elementos de uma população. Neste caso a amostra de 8 IES representa, percentualmente, aproximadamente 35\% (trinta e cinco por cento) da população estudada.

No Quadro 2 apresentamos, ordenadas aleatoriamente, as IES pesquisadas.

Quadro 2: IES pesquisadas.

\begin{tabular}{|l|l|l|l|}
\hline Código & \multicolumn{1}{|c|}{ Instituição de Ensino } & \multicolumn{1}{c|}{ Município } & \multicolumn{1}{c|}{ Sigla } \\
\hline 1 & Universidade Paulista & Goiânia-GO & UNIP \\
\hline 2 & Faculdades Objetivo & Goiânia-GO & OBJETIVO \\
\hline 3 & Faculdade Alves Faria & Goiânia-GO & ALFA \\
\hline 4 & Faculdade Cambury & Goiânia-GO & CAMBURY \\
\hline 5 & Faculdade Anhanguera & Goiânia-GO & ANHANGUERA \\
\hline 6 & $\begin{array}{l}\text { Instituto de Ensino Superior de } \\
\text { Brasília }\end{array}$ & Goiânia-GO & IESB \\
\hline 7 & Faculdade Lions & Brasília-DF & LIONS \\
\hline 8 & $\begin{array}{l}\text { Instituto de Ensino Superior de } \\
\text { Cuiabá }\end{array}$ & Cuiabá-MT & CUIABÁ \\
\hline
\end{tabular}

3.4 - Procedimentos da pesquisa

De posse das ementas, estudou-se exaustivamente os conteúdos programáticos e as referências bibliográficas básicas e complementares, tabulando-os da seguinte forma:

a) Conteúdo Programático: todos os itens constantes dos diversos conteúdos programáticos foram tabulados em uma pasta de trabalho de uma planilha de cálculo do Microsoft Excel, com o objetivo de verificar as coincidências de conteúdos por IES, gerando cálculos estatísticos, porcentagens e gráficos, para melhor entendimento e análise das informações; 
b) Referências bibliográficas básicas e complementares: utilizou-se o mesmo método acima, ordenando as informações por autor, possibilitando a verificação de quantidade e o grau de coincidência.

O segundo passo foi a realização de uma pesquisa bibliográfica, buscando a compilação de normas legais que regulamentam a organização curricular dos cursos de Turismo, incluindo-se especialmente a legislação emanada do MEC e do CNE sobre o assunto, além de propostas das entidades de classes que atuam e regulamentam a atividade turística no Brasil, como a ABBTUR, ABEDTH, EMBRATUR. 
4 - Resultados da Pesquisa

4.1 - Tabulação dos conteúdos programáticos

Os conteúdos programáticos das IES foram analisados individualmente, agrupando-os por assuntos, possibilitando, assim, a verificação dos itens comuns às diversas ementas. O resultado está apresentado na Tabela 2.

Tabela 2: Tabulação dos conteúdos programáticos.

\begin{tabular}{|c|c|c|c|c|c|c|c|c|c|c|}
\hline \multirow[b]{2}{*}{ Seq. } & \multirow[b]{2}{*}{ Conteúdo } & \multicolumn{8}{|c|}{ Instituições de Ensino superior } & \multirow{2}{*}{$\begin{array}{l}\text { Frequên } \\
\text { cia }\end{array}$} \\
\hline & & 1 & 2 & 3 & 4 & 5 & 6 & 7 & 8 & \\
\hline 1 & Fundamentos da Administração & & & & & & & & & \\
\hline 1.1 & $\begin{array}{l}\text { Evolução histórica da } \\
\text { administração }\end{array}$ & Sim & Sim & Sim & & Sim & & & & 4 \\
\hline 1.2 & Teoria da Administração Científica & Sim & Sim & Sim & Sim & Sim & Sim & Sim & & 7 \\
\hline 1.3 & Teoria Clássica & Sim & Sim & Sim & Sim & Sim & Sim & Sim & & 7 \\
\hline 1.4 & Teoria da Burocracia & & & Sim & Sim & Sim & Sim & Sim & & 5 \\
\hline 1.5 & Teoria das Relações Humanas & & & Sim & Sim & Sim & Sim & Sim & & 5 \\
\hline 1.6 & Teoria Comportamental & & & Sim & Sim & Sim & Sim & Sim & & 5 \\
\hline 1.7 & Enfoque Sistêmico & & & Sim & Sim & Sim & Sim & Sim & & 5 \\
\hline 1.8 & Teoria da Contingência & & & Sim & Sim & Sim & Sim & Sim & & 5 \\
\hline 1.9 & $\begin{array}{l}\text { Conceitos de Administração } \\
\text { (Processo Administrativo) }\end{array}$ & Sim & Sim & Sim & Sim & Sim & Sim & & Sim & 7 \\
\hline 1.10 & $\begin{array}{l}\text { Papeis, habilidades e Funções do } \\
\text { Administrador }\end{array}$ & Sim & Sim & Sim & Sim & Sim & & Sim & Sim & 7 \\
\hline 1.11 & $\begin{array}{l}\text { Conceito de Organização (Sistema } \\
\text { Empresarial) }\end{array}$ & Sim & Sim & & & Sim & & & Sim & 4 \\
\hline 2 & Processos Organizacionais e Adr & minis & trati & os & & & & & & \\
\hline 2.1 & Organização & & & & & & & & & \\
\hline 2.1 .1 & $\begin{array}{l}\text { Definição (Organização formal e } \\
\text { informal) }\end{array}$ & Sim & Sim & Sim & Sim & Sim & & Sim & Sim & 7 \\
\hline 2.1 .2 & $\begin{array}{l}\text { Divisão do trabalho } \\
\text { (Departamentalização) }\end{array}$ & & & Sim & Sim & & & & & 2 \\
\hline 2.1 .3 & Modelos Organizacionais & & & Sim & Sim & Sim & & Sim & Sim & 5 \\
\hline 2.1 .4 & Estrutura Organizacional & & & Sim & Sim & Sim & & Sim & Sim & 5 \\
\hline 2.1 .5 & $\begin{array}{l}\text { Dinâmica organizacional, } \\
\text { mudanças e inovações }\end{array}$ & & & & & & & & Sim & 1 \\
\hline 2.1 .6 & Desenho de cargos e tarefas & & & Sim & Sim & & & & Sim & 3 \\
\hline
\end{tabular}




\begin{tabular}{|c|c|c|c|c|c|c|c|c|c|c|}
\hline 2.1 .7 & $\begin{array}{l}\text { Análise do processo } \\
\text { Organizacional e Administrativo }\end{array}$ & & & & & Sim & & $\operatorname{Sim}$ & Sim & 4 \\
\hline 2.2 & Direção & & & & & & & & & \\
\hline 2.2 .1 & $\begin{array}{l}\text { A função Direção e os níveis } \\
\text { hierárquicos }\end{array}$ & & & Sim & & Sim & & & Sim & 3 \\
\hline 2.2 .2 & Noções de Direção & Sim & Sim & & Sim & Sim & & Sim & Sim & 6 \\
\hline 2.2 .3 & Administração participativa & & & Sim & & & & & & 1 \\
\hline 2.2 .4 & Motivação & & & Sim & Sim & & & Sim & & 3 \\
\hline 2.2 .5 & Desempenho & & & & & & & Sim & & 1 \\
\hline 2.2 .6 & Satisfação & & & & & & & Sim & & 1 \\
\hline 2.2 .7 & Liderança & & & Sim & Sim & & & Sim & & 3 \\
\hline 2.2 .8 & Dinâmica de Grupo & & & & & & & Sim & & 1 \\
\hline 2.2 .9 & Comunicação & & & Sim & Sim & & & Sim & & 3 \\
\hline $2.2 .1 \mathrm{C}$ & Negociação & & & & & & & Sim & & 1 \\
\hline 2.2 .11 & Sistemas de Administração & & & Sim & & & & & & 1 \\
\hline 2.3 & Controle & & & & & & & & & \\
\hline 2.3 .1 & Processo de Controle & Sim & Sim & Sim & Sim & Sim & & & Sim & 6 \\
\hline 2.3 .2 & Noções Gerais de Controle & Sim & Sim & & Sim & Sim & & Sim & Sim & 6 \\
\hline 2.3 .3 & O Controle eficaz & & & & & & & Sim & & 1 \\
\hline 2.3 .4 & O Controle Operacional & & & & & & & Sim & & 1 \\
\hline 2.3 .5 & Sistema de Informações Gerenciais & & & & & & & Sim & & 1 \\
\hline 2.3 .6 & Estratégias de Controle & & & & $\operatorname{sim}$ & Sim & & & & 2 \\
\hline 2.4 & Planejamento & & & & & & & & & \\
\hline 2.4 .1 & Noções gerais de Planejamento & Sim & Sim & & Sim & Sim & & Sim & Sim & 6 \\
\hline 2.4 .2 & Estratégia Empresarial & & & Sim & & Sim & & & & 2 \\
\hline 2.4 .3 & $\begin{array}{l}\text { Missão, Visão, Objetivos, Política e } \\
\text { Estratégias }\end{array}$ & & & Sim & & & & & Sim & 2 \\
\hline 2.4 .4 & Planejamento e os seus níveis & & & Sim & & & & & Sim & 2 \\
\hline 2.4 .5 & Planejamento Estratégico & & & & & & & Sim : & Sim & 2 \\
\hline 2.4 .6 & Planejamento Gerencial & & & & & & & Sim & Sim & 2 \\
\hline 2.4 .7 & Ferramentas de Planejamento & & & & & & & Sim & & 1 \\
\hline 2.4 .8 & Tomada de decisão & & & Sim & Sim & & & Sim & & 3 \\
\hline 2.4 .9 & $\begin{array}{l}\text { Abordagem Estratégica das } \\
\text { empresas. Formas de } \\
\text { dimensionamento, valorização e } \\
\text { competitividade }\end{array}$ & & & & & Sim & $\operatorname{Sim}$ & & & 2 \\
\hline 3 & Evolução da Administração & & & & & & & & & \\
\hline 3.1 & $\begin{array}{l}\text { Administração conteporânea e } \\
\text { seus desafios }\end{array}$ & & & Sim & & & & & & 1 \\
\hline 3.2 & Atividades interpessoais & & & & & & & Sim & & 1 \\
\hline 3.3 & $\begin{array}{l}\text { Níveis hierárquicos e competências } \\
\text { gerenciais }\end{array}$ & & & & & & & $\operatorname{Sim}$ & & 1 \\
\hline 3.4 & Tendências da Administração & & & Sim & & & & & & 1 \\
\hline 3.5 & Parceria & Sim & Sim & & & & $\operatorname{Sim}$ & & & 3 \\
\hline
\end{tabular}




\begin{tabular}{|c|c|c|c|c|c|c|c|}
\hline 3.6 & Terceirização & Sim & Sim & & & Sim & 3 \\
\hline 3.7 & Reengenharia & Sim & Sim & & & Sim & 3 \\
\hline 3.8 & Joint-ventur & Sim & Sim & & & Sim & 3 \\
\hline 3.9 & Empowerment & Sim & Sim & Sim & & & 3 \\
\hline 3.10 & Qualidade total & Sim & Sim & & & Sim & 3 \\
\hline 3.11 & Incorporação & Sim & Sim & & & & 2 \\
\hline 3.12 & Controle & Sim & Sim & & & Sim & 3 \\
\hline 3.13 & Franquia & Sim & Sim & & & & 2 \\
\hline 3.14 & O que é Ética & & & Sim & & Sim & 2 \\
\hline 3.15 & Responsabilidade Empresarial & & & & & Sim & 1 \\
\hline 3.16 & Cases & Sim & Sim & & & & 2 \\
\hline 4 & Ambiente de Negócios & & & & & & \\
\hline 4.1 & Os ambientes da Organização & & & & Sim & & 1 \\
\hline 4.1 .1 & $\begin{array}{l}\text { Macroambiente Administrativo: } \\
\text { econômico, tecnológico, } \\
\text { demográfico e ambiental }\end{array}$ & & & Sim & Sim & Sim & 3 \\
\hline 4.1 .2 & $\begin{array}{l}\text { Ambientes Competitivos: } \\
\text { concorrentes, entrantes, } \\
\text { substitutos, fornecedores e } \\
\text { consumidores }\end{array}$ & & & Sim & $\operatorname{Sim}$ & Sim & 3 \\
\hline 4.2 & $\begin{array}{l}\text { Por que as organizações são } \\
\text { necessárias? }\end{array}$ & & & Sim & & & 1 \\
\hline 4.3 & As funções da Empresa & & & Sim & & & 1 \\
\hline 4.4 & Níveis hierárquicos da Empresa & & & Sim & & & 1 \\
\hline 4.5 & $\begin{array}{l}\text { A Globalização e a gestão nas } \\
\text { Empresas }\end{array}$ & Sim & Sim & & & & 2 \\
\hline 4.6 & Competitividade: estudo de cluster & Sim & Sim & & & & 2 \\
\hline 4.7 & $\begin{array}{l}\text { Oportunidade de negócios. } \\
\text { Projeção no desenvolvimento } \\
\text { econômico. }\end{array}$ & & & & & Sim & 1 \\
\hline 4.8 & $\begin{array}{l}\text { Transformação de conhecimento } \\
\text { em Negócio. Processos de } \\
\text { transferência de competências. }\end{array}$ & & & & & Sim & 1 \\
\hline 4.9 & $\begin{array}{l}\text { Turismo e Sociedades } \\
\text { conteporâneas. O TurisBusiness }\end{array}$ & & & & & Sim & 1 \\
\hline 5 & Administração da Qualidade para & $10 \mathrm{Tu}$ & urism & & & & \\
\hline 5.1 & Controle da Qualidade Total (TQC) & Sim & Sim & & & Sim & 3 \\
\hline 5.2 & $\begin{array}{l}\text { Gestão da Qualidade em destinos } \\
\text { turísticos }\end{array}$ & Sim & Sim & & & Sim & 3 \\
\hline 6 & Gestão aplicada ao Turismo & & & & & & \\
\hline 6.1 & $\begin{array}{l}\text { Gestão nos principais segmentos } \\
\text { do mercado turísticos ( } \\
\text { agenciamento, hospedagem, } \\
\text { modais, parques, eventos, } \\
\text { recreação, consultoria e } \\
\text { restaurantes) }\end{array}$ & Sim & Sim & & Sim & & 3 \\
\hline
\end{tabular}




\begin{tabular}{|c|c|c|c|c|c|c|c|c|}
\hline 6.2 & Gestão Pública no Turismo & Sim & Sim & & Sim & & & 3 \\
\hline 6.3 & Gestão de Planos e Projetos & Sim & Sim & & & & & 2 \\
\hline 6.4 & Gestão Ambiental & Sim & Sim & & & & & 2 \\
\hline 6.5 & Gestão de Cluster: "Case Caribe" & Sim & Sim & & & & & 2 \\
\hline 6.6 & $\begin{array}{l}\text { Mudanças de Paradigmas em } \\
\text { Gestões Administrativas: } \\
\text { vantagens, obstáculos e } \\
\text { repercussões nas Organizações }\end{array}$ & & & & $\operatorname{Sim} s$ & Sim & & 2 \\
\hline 6.7 & Gestão de Recursos Humanos & & & & & & $\operatorname{Sim}$ & 1 \\
\hline 7 & \multicolumn{8}{|c|}{ Formação e origem do conhecimento } \\
\hline 7.1 & $\begin{array}{l}\text { O emprego na era do } \\
\text { conhecimento }\end{array}$ & & & Sim & & & & 1 \\
\hline 7.2 & O executivo para o novo cenário & & & Sim & & & & 1 \\
\hline 8 & \multicolumn{8}{|c|}{ Inserção do profissional de Turismo e Hotelaria no mercado de trabalho } \\
\hline 8.1 & Mercado de trabalho & & & Sim & & & & 1 \\
\hline 8.2 & Papel do Profissional & & & Sim & & Sim & & 2 \\
\hline 8.3 & Perspectivas & & & Sim & & & & 1 \\
\hline
\end{tabular}

Fonte: Ementas das IES pesquisadas

A Tabela 3 apresenta o resumo da tabulação dos conteúdos programáticos das IES pesquisadas, com a totalização e cálculo da freqüência relativa, desvio padrão e da média aritmética.

Tabela 3: Quantidade de conteúdo programático por IES.

\begin{tabular}{|l|c|c|c|}
\hline \multicolumn{1}{|c|}{ IES } & Quantidade & Freqüência relativa & $\begin{array}{c}\text { Frequência relativa } \\
\text { acumulada }\end{array}$ \\
\hline UNIP & 30 & $13,10 \%$ & $13,10 \%$ \\
\hline OBJETIVO & 30 & $13,10 \%$ & $26,20 \%$ \\
\hline ALFA & 40 & $17,47 \%$ & $43,67 \%$ \\
\hline CAMBURY & 23 & $10,04 \%$ & $53,71 \%$ \\
\hline ANHANGUERA & 29 & $12,66 \%$ & $66,38 \%$ \\
\hline IESB & 27 & $11,79 \%$ & $78,17 \%$ \\
\hline LIONS & 31 & $13,54 \%$ & $91,70 \%$ \\
\hline CUIABÁ & 19 & $8,30 \%$ & $100,00 \%$ \\
\hline Total & $\mathbf{2 2 9}$ & $\mathbf{1 0 0 , 0 0 \%}$ & \\
\hline Desvio Padrão & $\mathbf{6}$ & & \\
\hline Média & $\mathbf{2 9}$ & & \\
\hline
\end{tabular}

O Gráfico 1, representa bem através de suas colunas a movimentação da quantidade de conteúdo programático adotado pelas IES. 
Gráfico 1: Quantidade de conteúdo programático por IES

\section{Quantidade de conteúdo programático por IES}

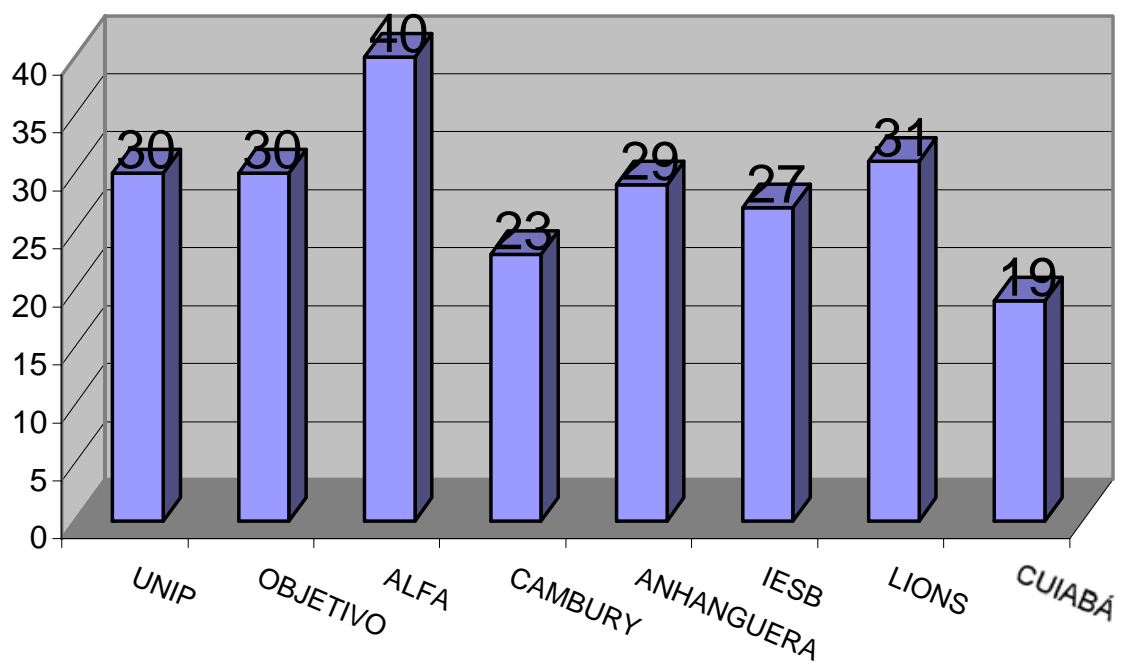

Os conteúdos programáticos comuns às diversas IES, também foram observados conforme consta da Tabela 4.

Tabela 4: Totalização de conteúdos programáticos comuns às IES.

\begin{tabular}{|c|c|c|c|}
\hline $\begin{array}{c}\text { Quantidade de vezes que } \\
\text { o conteúdo programático } \\
\text { foi adotado pelas IES }\end{array}$ & Itens & Freqüência relativa & $\begin{array}{c}\text { Freqüência relativa } \\
\text { acumulada }\end{array}$ \\
\hline 1 & 28 & $32,94 \%$ & $32,94 \%$ \\
\hline 2 & 19 & $22,35 \%$ & $55,29 \%$ \\
\hline 3 & 19 & $22,35 \%$ & $77,65 \%$ \\
\hline 4 & 3 & $3,53 \%$ & $\mathbf{8 1 , 1 8 \%}$ \\
\hline 5 & 7 & $\mathbf{8 , 2 4 \%}$ & $\mathbf{8 9 , 4 1 \%}$ \\
\hline 6 & 4 & $4,71 \%$ & $\mathbf{9 4 , 1 2 \%}$ \\
\hline 7 & 5 & $5,88 \%$ & $100,00 \%$ \\
\hline Total & 85 & $100,00 \%$ & \\
\hline
\end{tabular}

O Gráfico 2, abaixo, representa os dados da Tabela 4, refletindo visualmente as informações apresentadas. 
Gráfico 2: Quantidade de vezes que o conteúdo foi adotado pelas IES

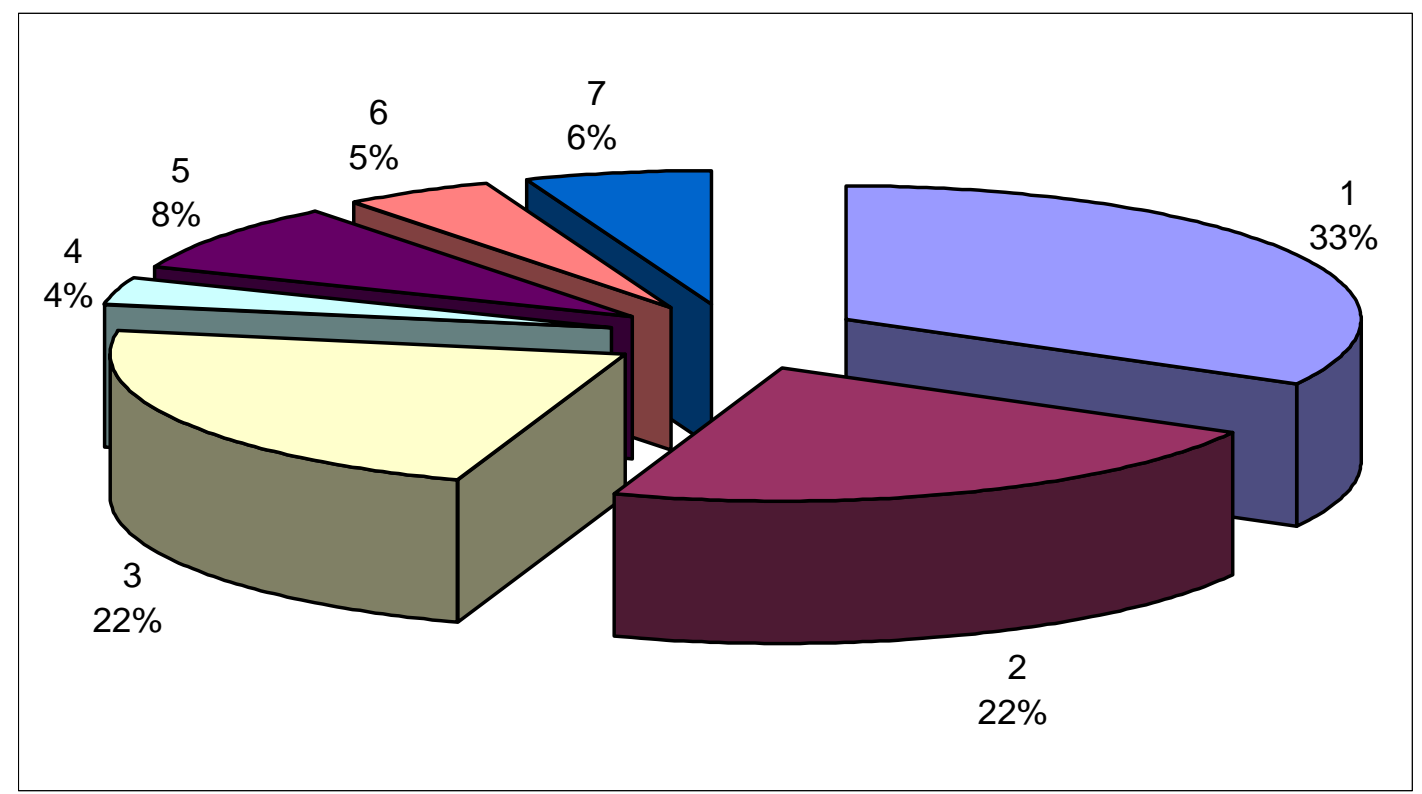

A Tabela 5 apresenta os dados tabulados por grupos de conteúdos programáticos, conforme foi apresentado na Tabela 2, resultando na seguinte informação apresentada abaixo.

Tabela 5: Agrupamento dos conteúdos programáticos por assuntos ou títulos.

\begin{tabular}{|l|c|c|c|}
\hline Assunto/Título & $\begin{array}{l}\text { Quantidade } \\
\text { de conteúdo }\end{array}$ & $\begin{array}{l}\text { Freqüência } \\
\text { relativa (\%) }\end{array}$ & $\begin{array}{l}\text { Freqüência relativa } \\
\text { acumulada (\%) }\end{array}$ \\
\hline $\begin{array}{l}\text { 1 - Fundamentos da } \\
\text { Administração }\end{array}$ & 61 & 26,60 & 26,60 \\
\hline $\begin{array}{l}2-\text { Processos Organizacionais } \\
\text { e Administrativos }\end{array}$ & & & \\
\hline 2.1 - Organização & 27 & 11,80 & 38,40 \\
\hline 2.2 - Direção & 24 & 10,50 & 48,90 \\
\hline $2.3-$ Controle & 17 & 7,40 & 56,30 \\
\hline $\begin{array}{l}2.4-\text { Planejamento } \\
\text { 3- Evolução da Administração }\end{array}$ & 22 & 9,60 & 65,90 \\
\hline $\begin{array}{l}4-\text { Ambiente de Negócios } \\
\text { 5 - Administração da Qualidade } \\
\text { para o Turismo }\end{array}$ & 17 & 14,90 & 80,80 \\
\hline 6 - Gestão aplicada ao Turismo & 15 & 7,40 & 90,80 \\
\hline $\begin{array}{l}\text { 7 - Formação e origem do } \\
\text { conhecimento }\end{array}$ & 2 & 2,60 & 97,40 \\
\hline $\begin{array}{l}\text { 8 - Inserção do profissional de } \\
\text { Turismo no mercado de } \\
\text { trabalho }\end{array}$ & 4 & 0,90 & 98,30 \\
\hline Total & & 1,70 & 100,00 \\
\hline
\end{tabular}


4.2 - Tabulação das Referências Bibliográficas

Utilizando-se a mesma metodologia para a tabulação dos conteúdos programáticos, tabulou-se as informações referentes às referências bibliográficas básicas e complementares adotadas pelas IES pesquisadas, obtendo-se os resultados apresentados nas Tabelas 6 e 7.

Tabela 6: Tabulação das referências bibliográficas básicas.

\begin{tabular}{|c|c|c|c|c|c|c|c|c|c|}
\hline \multirow[b]{2}{*}{ Bibliografia básica } & \multicolumn{8}{|c|}{ Instituições de Ensino } & \multirow[b]{2}{*}{ Total } \\
\hline & 1 & 2 & 3 & 4 & 5 & 6 & 7 & 8 & \\
\hline $\begin{array}{l}\text { ACERENZA, Miguel Angel. } \\
\text { Adminstração do turismo. Edusc, } 2002\end{array}$ & & & & & Sim & & & & 1 \\
\hline $\begin{array}{l}\text { ALBRECHT, Karl. Programando o } \\
\text { Futuro. São Paulo : Makron Books, } 1994 .\end{array}$ & Sim & Sim & & & & & & & 2 \\
\hline $\begin{array}{l}\text { ALBRECHT, Karl. Revolução nos } \\
\text { serviços. São Paulo : Pioneira, } 1992 .\end{array}$ & Sim & Sim & & & & & & & 2 \\
\hline 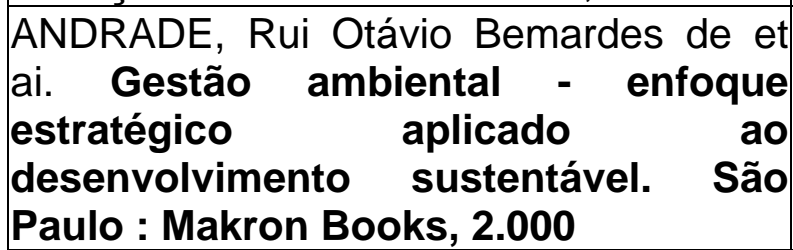 & Sim & $\operatorname{Sim}$ & & & & & & & 2 \\
\hline $\begin{array}{l}\text { BARROS, Claudius Dártagnan C. } \\
\text { Excelência em serviços-questão de } \\
\text { sobrevivência no mercado. São Paulo: } \\
\text { Qualítymark, } 1996 .\end{array}$ & Sim & Sim & & & & & & & 2 \\
\hline $\begin{array}{l}\text { BERNARDES,C.; MARCONDES,R.C., } \\
\text { Teoria Geral da Administração: } \\
\text { gerenciando organizações. São Paulo: } \\
\text { Saraviva, } 2003 .\end{array}$ & & & & & & Sim & & & 1 \\
\hline $\begin{array}{l}\text { BOTELHO, E Administração } \\
\text { inteligente: A revolução } \\
\text { Administrativa. São Paulo : Atlas, } 1996\end{array}$ & & & & & Sim & & & & 1 \\
\hline $\begin{array}{l}\text { CAMPOS, Vicente Falconi. TQC - } \\
\text { Controle da Qualidade Total. Rio de } \\
\text { Janeiro : Block, } 1992 .\end{array}$ & Sim & Sim & & & & & & & 2 \\
\hline $\begin{array}{l}\text { CASTELLI, Geraldo. Turismo-atividade } \\
\text { marcante. } 4^{\circ} \text { ed. Revisado e Ampliado. } \\
\text { Caxias do Sul:EDUCS, } 2001 .\end{array}$ & Sim & Sim & & & & & & & 2 \\
\hline
\end{tabular}


CAVASSA, César Ramirez. Hotéis Gerenciamento, Segurança e Manutenção. Trad. Cláudia Bruno Galvãn. São Paulo: Roca, 2001.

CERTO, S. C. Peter. Administração estratégica. São Paulo : Makron, 1993

\begin{tabular}{|l|l|l|l|l|l|l|l|l|}
\hline \multicolumn{1}{|l|}{} & & & & & & & \\
Sim & Sim & & & & & & $\mathbf{2}$ \\
\hline & & & & & & & & \\
\hline & & & & & & & & \\
\hline & & & & & & & \\
\hline
\end{tabular}
1995.

COBRA, Marcos. Administração: evolução, desafios, tendências. $1^{\circ} \mathrm{ed}$. São Paulo: Cobra, 2001. DRUCKER, Peter, Introdução ã Administração, 3a. ed. São Paulo, Pioneira. 1977. DUBRIN, Andrew J. Princípios de Administração. Rio de Janeiro. LTC, 1999

FAYOL, H. Administração Industrial e Geral. São Paulo : Atlas, 1999. FERREIRA, A. A. Gestão Empresarial: de Taylor aos Nossos Dias. SP. Pioneira, 1997.

FITZSIMMONS, James ; FITZSIMMONS, Mona. Administração de serviços: operações, estratégia de marketing e tecnologia de informação. $2^{\circ}$ ed. São Paulo: Bookman, 2000. FLORES, Paulo Silas Ozores. Treinamento em qualidade. Fator de sucesso para desenvolvimento de hotelaria e turismo. São Paulo: Roca, 2002

FONSECA, Marcelo Traldi. Tecnologias gerenciais de restaurantes. São Paulo: SENAC, 2000.

GALBRAITH, J. K. Organizando para competir no futuro. São Paulo : Makron, 1995

GONÇALVES, Maria Helena B.

Administração mercadológica. $2^{\circ}$ ed. São Paulo: SENAC, 2000. 
KWASNICKA, Eunice Lacava.

Introdução à Administração. São Paulo:

Atlas, 1995.

LATTIN, Geraíd W. Administración

moderna de hoteles y moteles. México:

Trilias, 1994.

LONGNEKER, J. G. et alii.

Administração de pequenas empresas.

São Paulo : Makron Books, 1997.

MAXIMIANO, A. C. A. Introdução à

Administração. São Paulo: Atlas, 1995.

MAXIMIANO, A. C. A. Teoria Geral da

Administração: da escola científica à competitividade da economia global.

$2^{\circ}$ ed. São Paulo: Atlas, 2000.

\begin{tabular}{|l|l|l|l|l|l|l|l|l|}
\hline Sim & Sim & & & & & & & $\mathbf{2}$ \\
\hline & & & & & & & & \\
\hline & & & & & & & & 1 \\
\hline
\end{tabular}

MEGGINSON, Leon Donald Mosley \& JR. Paul Petri. Administração: Conceitos e aplicações. São Paulo. Harbra, 1998.

MONTANA, Patrick J. Administração.

São Paulo: Saraiva, 1998.

MORAES, Anna Maris Pereira, Iniciação ao Estudo da Administração, São

Paulo, Makron Books, 2000

MOTA, Fernando Peter. Teoria Geral da

Administração. São Paulo : Pioneira,

1999

PARK, Kil Hyang. Introdução ao Estudo da Administração. São Paulo: Pioneira, 1997.

ROCHA, Cristobal Casanueva, JUNCO, Júlio Garcia dei e GONZALEZ, Francisco Javier Caro. Organización y gestión de empresas turísticas. Madrid: Pirâmide, 2000.

SANTOS, Milton. Por uma outra globalização do pensamento único à consciência universal. Rio de Janeiro : Record, 2001.

SCHMENNER, Roger W. Trad. Lenker Feres. Administração de operações em serviços. São Paulo: Futura, 1999.

TEIXEIRA, Elder Lins. Gestão da qualidade em destinos turísticos. Rio de Janeiro: Qualitymark, 1999.

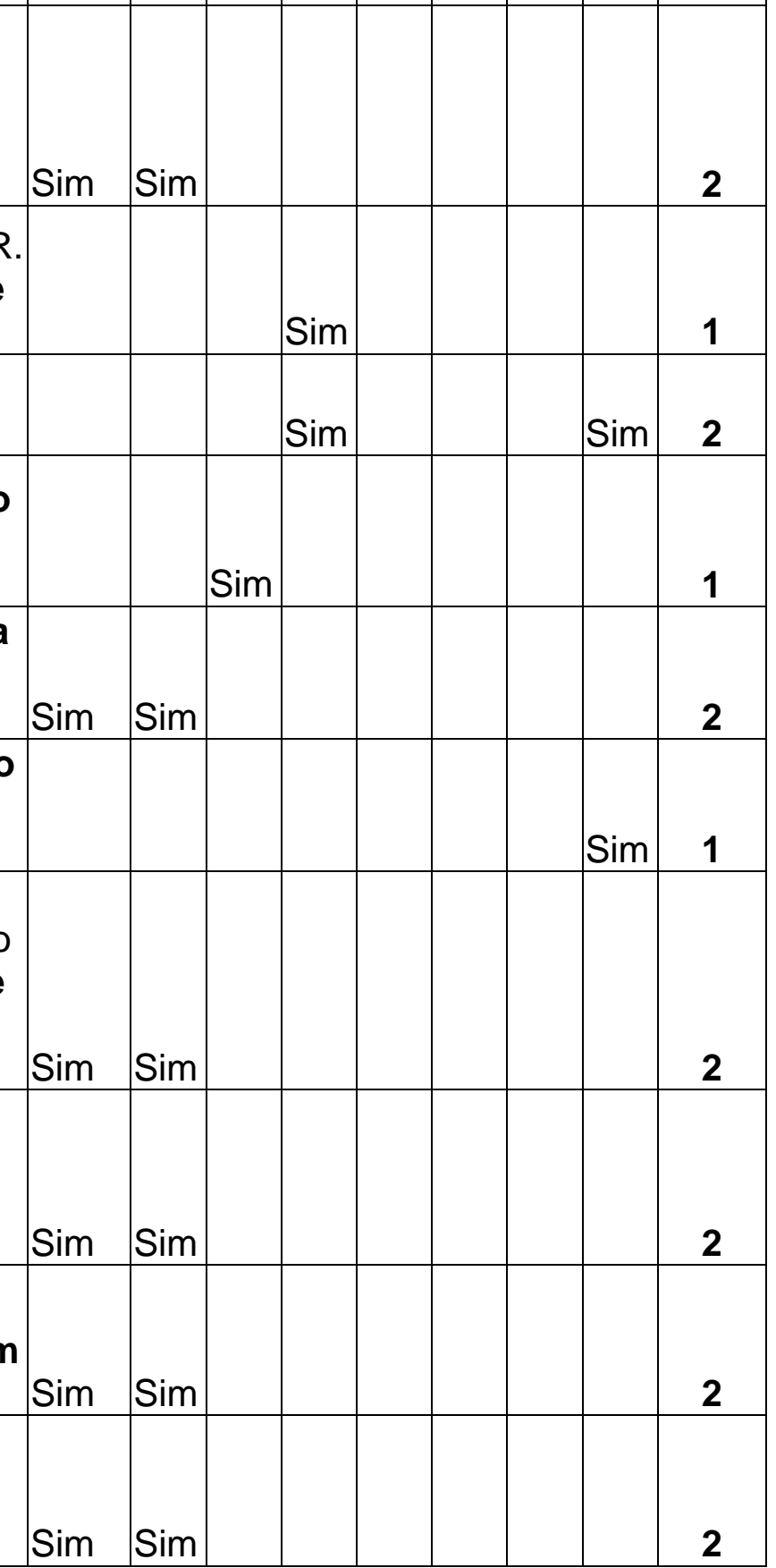




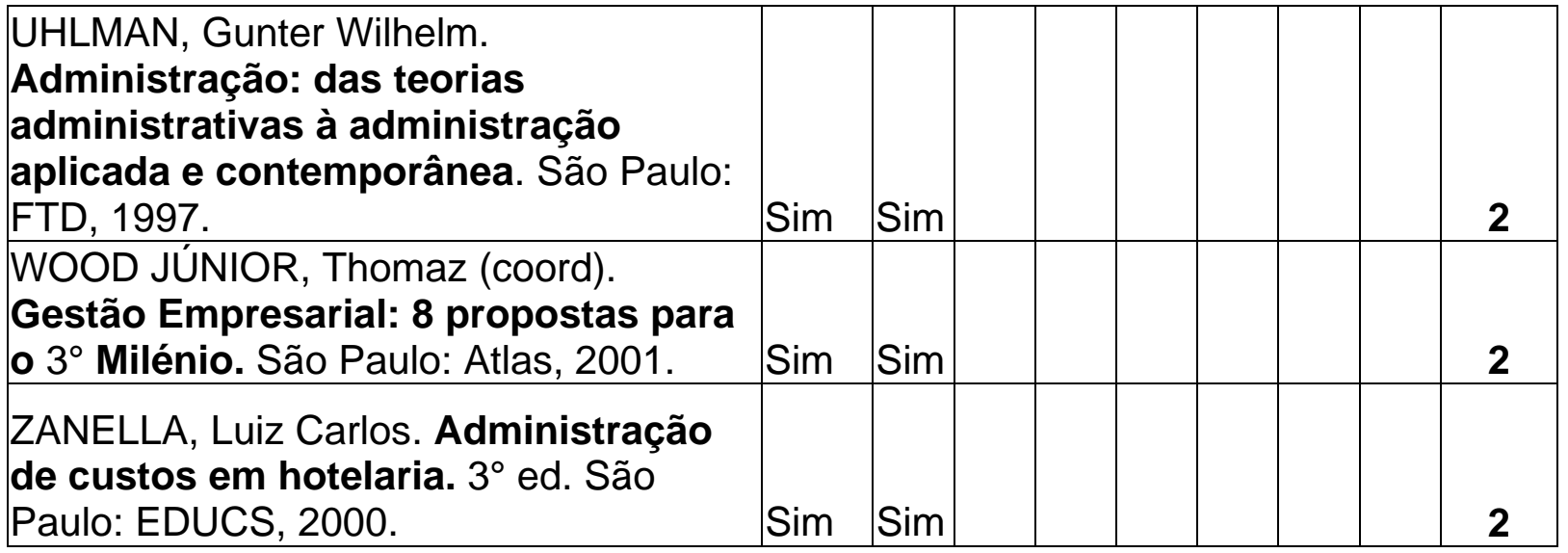

Fonte: Ementas das IES pesquisadas

Tabela 7: Tabulação das referências bibliográficas complementares.

\begin{tabular}{|c|c|c|c|c|c|c|c|c|}
\hline \multirow[b]{2}{*}{ Bibliografia complementar } & \multicolumn{7}{|c|}{ Instituições de Ensino } & \multirow[t]{2}{*}{ Total } \\
\hline & 1 & 2 & 3 & 4 & 5 & 6 & 7 & \\
\hline $\begin{array}{l}\text { ACERENZA, Angel, Miguel. } \\
\text { Administración dei turismo. México: } \\
\text { Trilias, 1998. VI. }\end{array}$ & Sim & Sim & & & & Sim & Sim & 4 \\
\hline $\begin{array}{l}\text { ACKOFF, R.L. Planejamento } \\
\text { Empresarial. Rio de Janeiro: Livros } \\
\text { Técnicos e Científicos, } 1975 \\
\end{array}$ & & & Sim & & & & & 1 \\
\hline $\begin{array}{l}\text { ALBRECHT, Karl. Programando o } \\
\text { Futuro. São Paulo, Makron Books, } 1994 .\end{array}$ & & & Sim & & & & & 1 \\
\hline $\begin{array}{l}\text { ALBRECHT, Karl. Revolução nos } \\
\text { serviços. São Paulo, Pioneira, } 1992 .\end{array}$ & & & Sim & & & & & 1 \\
\hline $\begin{array}{l}\text { ALFONSO, E. \& DÍAZ, H. Planificacion } \\
\text { Turística: Un Enfoque Metodológico. } \\
\text { México: Trillas, } 1982\end{array}$ & & & & & & Sim & & 1 \\
\hline $\begin{array}{l}\text { ANDRADE, J. V. Turismo: } \\
\text { Fundamentos e Dimensões. São Paulo: } \\
\text { Ed. Ática, 1998. }\end{array}$ & & & & & & Sim & & 1 \\
\hline $\begin{array}{l}\text { ANSARAH, M. G. R. Turismo - o que } \\
\text { você precisa saber para investir no } \\
\text { setor. São Paulo: SEBRAE, } 1996 .\end{array}$ & & & & & & Sim & & 1 \\
\hline $\begin{array}{l}\text { ANSARAH, M. G. R.(Org.) Turismo: } \\
\text { segmentação de mercado. São Paulo: } \\
\text { Futura, } 1999 .\end{array}$ & & & & & & Sim & & 1 \\
\hline $\begin{array}{l}\text { AZEVEDO, João H. de. Como iniciar } \\
\text { uma empresa de sucesso. São Paulo : } \\
\text { Qualitymark, } 1996 .\end{array}$ & & & & & Sim & & & 1 \\
\hline $\begin{array}{l}\text { BARRETO, M. B. Planejamento e } \\
\text { Organização em Turismo. Campinas, } \\
\text { SP: Papirus, } 1991 .\end{array}$ & & & & & & Sim & & 1 \\
\hline
\end{tabular}


BARROS, Claudius Dártagnan C.

Excelência em serviços - questão de sobrevivência no mercado. São Paulo, Qualitymark.

BENI, M. C. Análise Estrutural do

Turismo. São Paulo: Ed. SENAC, 1997.

BOTELHO, E Administração

inteligente: A revolução

Administrativa. São Paulo : Atlas, 1996

CAVASSA, C. R. Gestion

Administrativa para Empresas

Turísticas. México: Trillas, 1993.

CHIAVENATO, Idalberto, Administração

de Empresas - uma Abordagem

Contingência!. 4a. ed., São Paulo, Makron Books, 1991.

CHIAVENATO, Idalberto, Introdução à Teoria Geral da Administração. São

Paulo. Campus, 2001

DENCKER, A. F. M. Métodos e

Técnicas de Pesquisa em Turismo.

São Paulo: Futura, 1998.

DRUCKER, P. Introdução à

Administração. São Paulo: Pioneira, 1998.

DRUKER, P. F. A nova era da

Administração. São Paulo : Pioneira,

1989

DRUKER, P. F.Administração de organizações. São Paulo : Pioneira, 1994

ESTÚDIOS y Perspectivas en turismo.

1992. Buenos Aires: CIET, abr

FERREIRA, A. \& REIS, A. Gestão

Empresarial: de Taylor aos Nossos

Dias. São Paulo, Pioneira, 1992.

GALBRAITH, J. K. Organizando para

competir no futuro. São Paulo : Makron,

1995

GASTAL, S. et.al. Turismo: 9 Propostas

para um saber-fazer. s/c: Edição dos

Autores, 1998.

IGNARRA, L. R. Fundamentos do

Turismo. São Paulo: Pioneira, 1999.

KOONTZ \& O'DONNELL. Princípios de administração. São Paulo : Pioneira, 1970.

\begin{tabular}{ll|l|l}
$\operatorname{sim}$ & & & 1 \\
& & & 2 \\
\end{tabular}

1


LAGE, B. H.G. \& MILONE, P. C.

Turismo: teoria e prática. São Paulo:

Ed. Atlas, 2000.

LERNER, Walter. Organização

participativa: como a empresa

brasileira pode enfrentar esse desafio.

São Paulo : Nobel, 1991.

LODI, João Bosco, História da

Administração, 3a. ed. São Paulo,

Pioneira, 1983.

MASIERO, Gilmar. Introdução à

Administração. São Paulo. Atlas, 1998

MAXIMIANO, António César Amaru,

Introdução à Administração 5" edição.

São Paulo, Atlas, 1999.

MONTANA, Patrick, Administração. São

Paulo, Saraiva, 1998.

MORAES, Anna Maris Pereira de.

Iniciação ao Estudo da Administração.

São Paulo. Makron Books, 2000.

NAISBETT, John. Paradoxo global São

Paulo: Campus, 1997.

O.M.T. - Organización Mundial del

Turismo. Lo que Todo Gestor Turistico

Debe Saber. Madrid: OMT, 1997.

OLIVEIRA, Djalma de Pinho Rebouças.

Sistemas, Organização \& Métodos. 10a

edição. São Paulo, Atlas, 2000.

PETROCCHI, M. Turismo,

Planejamento e Gestão. São Paulo:

Futura, 1998.

PETROCCHI, Mário. Gestão de pólos

turísticos. São Paulo: Futura, 2001.

PINTO, Miguel, Fundamentos da

Administração no Turismo. Rio de Janeiro, Infobook. 2000.

RAIMUNDO, P. R. O que é

Administração: A análise integrada das organizações. São Paulo : Atlas, 1993.

RODRIGUES, A.B. (Org.) Turismo e

desenvolvimento Local. São Paulo: Ed.

Hucitec, 1997.

ROOS, Daniel, e outros. A Máquina que

mudou o mundo. Rio de Janeiro, Editora

Campus.

\begin{tabular}{|c|c|c|c|c|c|c|c|}
\hline & & & & & Sim & & 1 \\
\hline $\operatorname{Sim}$ & Sim & & & & & & 2 \\
\hline & & & & & & Sim & 1 \\
\hline & & & Sim & & & & 1 \\
\hline & & Sim & & & & & 1 \\
\hline & & $\operatorname{Sim}$ & & & & & 1 \\
\hline & & & Sim & & & & 1 \\
\hline Sim & Sim & $\operatorname{Sim}$ & & & & & 3 \\
\hline & & & & & Sim & & 1 \\
\hline & & Sim & & & & & 1 \\
\hline & & & & & Sim & & 1 \\
\hline Sim & Sim & & & & & & 2 \\
\hline & & & & & & Sim & 1 \\
\hline & & & & Sim & & & 1 \\
\hline & & & & & Sim & & 1 \\
\hline & & $\operatorname{Sim}$ & & & & & 1 \\
\hline
\end{tabular}




\begin{tabular}{|c|c|c|c|c|c|c|c|}
\hline $\begin{array}{l}\text { RUSCHMANN, D. van de M. Turismo e } \\
\text { Planejamento Sustentável: A proteção } \\
\text { do Meio Ambiente. Campinas, SP: } \\
\text { Papirus, } 1997 .\end{array}$ & & & & & Sim & & 1 \\
\hline $\begin{array}{l}\text { STONER, J. A. F.\& FREEMAN, R.E. } \\
\text { Administração. Rio de Janeiro: Prentice- } \\
\text { Hall, } 1985 .\end{array}$ & & & & & Sim & Sim & 2 \\
\hline $\begin{array}{l}\text { TABARES, F. C. Comercialización del } \\
\text { Turismo. México: Trillas, } 1990 .\end{array}$ & & & & & Sim & & 1 \\
\hline $\begin{array}{l}\text { TAPSCOTT, D. Mudanças de } \\
\text { paradigma. São Paulo : Makron, } 1995 .\end{array}$ & & & & Sim & & & 1 \\
\hline $\begin{array}{l}\text { TAYLOR, Frederick W., Princípios de } \\
\text { Administração Científica. São Paulo, } \\
\text { Editora Atlas }\end{array}$ & & & Sim & & & & 1 \\
\hline $\begin{array}{l}\text { THEOBALD, Willian F. (org.). Turismo } \\
\text { Global. São Paulo : SENAC, } 2001 .\end{array}$ & Sim & Sim & & & & & 2 \\
\hline $\begin{array}{l}\text { TRIGO, L. G.G. A Sociedade Pós- } \\
\text { Industrial e o Profissional em Turismo. } \\
\text { Campinas, SP: Papirus, } 1998 .\end{array}$ & & & & Sim & Sim & & 2 \\
\hline $\begin{array}{l}\text { TRIGO, Luiz Gonzaga G. Turismo } \\
\text { Básico. São Paulo: Ed. SENAC, } 1998 .\end{array}$ & & & & & Sim & & 1 \\
\hline $\begin{array}{l}\text { TRIGO, Luiz Gonzaga G. Turismo e } \\
\text { Qualidade : Tendências } \\
\text { contemporâneas. Campinas, SP: } \\
\text { Papirus,1993. }\end{array}$ & & & & Sim & Sim & & 2 \\
\hline $\begin{array}{l}\text { ULRICH, Dave et ali. Liderança } \\
\text { orientada para resultados. Como os } \\
\text { líderes constroem empresas e } \\
\text { aumentam a lucratividade. Trad. Afonso } \\
\text { Celso da Cunha Serpa. Rio de janeiro: } \\
\text { Campus, } 2000 \text {. }\end{array}$ & Sim & Sim & & & & & 2 \\
\hline $\begin{array}{l}\text { WALTON, Mary. O método Deming de } \\
\text { Administração. Rio de Janeiro: } \\
\text { Marques Saraiva, } 1989 .\end{array}$ & Sim & Sim & & & & & 2 \\
\hline
\end{tabular}

Fonte: Ementas das IES pesquisadas

A Tabela 8 apresenta os dados sintéticos das referências bibliográficas básicas e complementares, bem como a média, o desvio padrão e a participação percentual em relação ao total. 
Tabela 8: Dados sintéticos das referências bibliográficas.

\begin{tabular}{|l|c|c|c|c|}
\hline \multirow{2}{*}{\multicolumn{1}{c|}{ IES }} & \multicolumn{4}{|c|}{ BIBLIOGRAFIA } \\
\cline { 2 - 5 } & Básica & $\mathbf{\%}$ & Complementar & $\mathbf{\%}$ \\
\hline UNIP & $\mathbf{2 3}$ & $34,85 \%$ & $\mathbf{9}$ & $13,04 \%$ \\
\hline OBJETIVO & $\mathbf{2 3}$ & $34,85 \%$ & $\mathbf{9}$ & $13,04 \%$ \\
\hline ALFA & $\mathbf{1}$ & $1,52 \%$ & $\mathbf{1 0}$ & $14,49 \%$ \\
\hline CAMBURY & $\mathbf{3}$ & $4,55 \%$ & $\mathbf{4}$ & $5,80 \%$ \\
\hline ANHANGUERA & $\mathbf{6}$ & $9,09 \%$ & $\mathbf{9}$ & $13,04 \%$ \\
\hline IESB & $\mathbf{2}$ & $3,03 \%$ & $\mathbf{2 2}$ & $31,88 \%$ \\
\hline LIONS & $\mathbf{3}$ & $4,55 \%$ & $\mathbf{6}$ & $8,70 \%$ \\
\hline CUIABÁ & $\mathbf{5}$ & $7,58 \%$ & $\mathbf{0}$ & $0,00 \%$ \\
\hline Total & $\mathbf{6 6}$ & $100,00 \%$ & $\mathbf{6 9}$ & $100,00 \%$ \\
\hline Desvio & $\mathbf{8 , 6}$ & & $\mathbf{6 , 0}$ & \\
\hline Média & $\mathbf{8 , 3}$ & & $\mathbf{8 , 6}$ & \\
\hline
\end{tabular}

O Gráfico 3, abaixo, apresentados as quantidade de referência bibliográfica básica e complementar, ilustram a tabulação dos dados.

Gráfico 3: Quantidade de referência bibliográfica básica e complementar
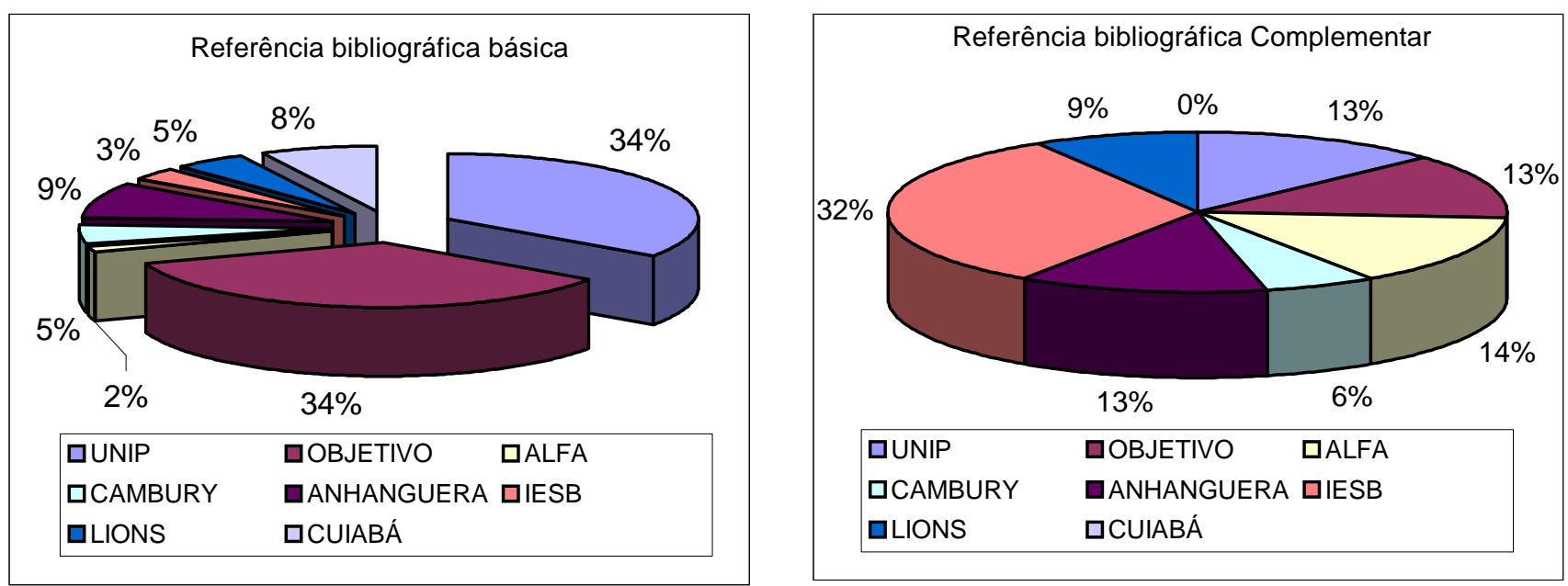

As Tabelas 9 e 10, abaixo, apresentam os dados referentes à quantidade de bibliografia básica e complementar adotada, que são comuns as IES pesquisadas. 
Tabela 9: Referências bibliográficas básicas comuns as IES.

\begin{tabular}{|c|c|c|}
\hline $\begin{array}{c}\text { Quantidade de } \\
\text { vezes adotadas }\end{array}$ & Referência bibliográfica & $\%$ \\
\hline 1 & 15 & $38 \%$ \\
\hline 2 & 24 & $60 \%$ \\
\hline 3 & 1 & $3 \%$ \\
\hline Total & 40 & $100 \%$ \\
\hline
\end{tabular}

Tabela 10: Referências bibliográficas complementares comuns as IES.

\begin{tabular}{|c|c|c|}
\hline $\begin{array}{c}\text { Quantidade de } \\
\text { vezes adotadas }\end{array}$ & Referência bibliográfica & $\%$ \\
\hline 1 & 40 & $75 \%$ \\
\hline 2 & 11 & $21 \%$ \\
\hline 3 & 1 & $2 \%$ \\
\hline 4 & 1 & $2 \%$ \\
\hline Total & 53 & $100 \%$ \\
\hline
\end{tabular}

As Tabelas 11 e 12, abaixo, foram produzidas com base nas Tabelas 6 e 7, verificando-se cada título da referência bibliográfica, com o objetivo de certificar se o referencial teórico foi produzido especificamente para a atividade turística ou se ele foi produzido para outro segmento da educação, neste caso, não fazendo o link com a atividade turística, sendo emprestado de outras áreas para compor o referencial teórico dos cursos de turismo.

Tabela 11: Referências bibliográficas básicas que fazem o link com o turismo

\begin{tabular}{|l|r|r|r|r|r|}
\hline \multicolumn{1}{|c|}{ IES } & \multicolumn{1}{c|}{ Sim } & \multicolumn{1}{c|}{ \% } & Não & \multicolumn{1}{c|}{ \% } & \multicolumn{1}{c|}{ Total } \\
\hline UNIP & $\mathbf{8}$ & $34,78 \%$ & $\mathbf{1 5}$ & $65,22 \%$ & $\mathbf{2 3}$ \\
\hline OBJETIVO & $\mathbf{8}$ & $34,78 \%$ & $\mathbf{1 5}$ & $65,22 \%$ & $\mathbf{2 3}$ \\
\hline ALFA & $\mathbf{0}$ & $0,00 \%$ & $\mathbf{1}$ & $100,00 \%$ & $\mathbf{1}$ \\
\hline CAMBURY & $\mathbf{0}$ & $0,00 \%$ & $\mathbf{3}$ & $100,00 \%$ & $\mathbf{3}$ \\
\hline ANHANGUERA & $\mathbf{1}$ & $16,67 \%$ & $\mathbf{5}$ & $83,33 \%$ & $\mathbf{6}$ \\
\hline IESB & $\mathbf{0}$ & $0,00 \%$ & $\mathbf{2}$ & $100,00 \%$ & $\mathbf{2}$ \\
\hline LIONS & $\mathbf{0}$ & $0,00 \%$ & $\mathbf{3}$ & $100,00 \%$ & $\mathbf{3}$ \\
\hline CUIABÁ & $\mathbf{0}$ & $0,00 \%$ & $\mathbf{5}$ & $100,00 \%$ & $\mathbf{5}$ \\
\hline Total & $\mathbf{1 7}$ & $25,76 \%$ & $\mathbf{4 9}$ & $74,24 \%$ & $\mathbf{6 6}$ \\
\hline
\end{tabular}


Tabela 12: Referências bibliográficas complementares que fazem o link com o turismo

\begin{tabular}{|l|c|c|c|c|c|}
\hline \multicolumn{1}{|c|}{ IES } & Sim & $\mathbf{\%}$ & Não & $\mathbf{\%}$ & Total \\
\hline UNIP & $\mathbf{4}$ & $44,44 \%$ & $\mathbf{5}$ & $55,56 \%$ & $\mathbf{9}$ \\
\hline OBJETIVO & $\mathbf{4}$ & $44,44 \%$ & $\mathbf{5}$ & $55,56 \%$ & $\mathbf{9}$ \\
\hline ALFA & $\mathbf{0}$ & $0,00 \%$ & $\mathbf{1 0}$ & $100,00 \%$ & $\mathbf{1 0}$ \\
\hline CAMBURY & $\mathbf{0}$ & $0,00 \%$ & $\mathbf{4}$ & $100,00 \%$ & $\mathbf{4}$ \\
\hline ANHANGUERA & $\mathbf{2}$ & $22,22 \%$ & $\mathbf{7}$ & $77,78 \%$ & $\mathbf{9}$ \\
\hline IESB & $\mathbf{1 9}$ & $86,36 \%$ & $\mathbf{3}$ & $13,64 \%$ & $\mathbf{2 2}$ \\
\hline LIONS & $\mathbf{2}$ & $33,33 \%$ & $\mathbf{4}$ & $66,67 \%$ & $\mathbf{6}$ \\
\hline CUIABÁ & $\mathbf{0}$ & $0,00 \%$ & $\mathbf{0}$ & $0,00 \%$ & $\mathbf{0}$ \\
\hline Total & $\mathbf{3 1}$ & $44,93 \%$ & $\mathbf{3 8}$ & $55,07 \%$ & $\mathbf{6 9}$ \\
\hline
\end{tabular}


5 - Discussão dos resultados da Pesquisa

$\mathrm{Na}$ tabulação dos conteúdos programáticos podemos verificar que existe uma tendência para a média aritmética, ou seja, 29 conteúdos por IES. Observamos que o maior dado, ou maior quantidade de conteúdo programático é de 40 itens da Faculdade Alfa, enquanto o menor é de 19 itens adotados pela Faculdade de Cuiabá. Estes resultados demonstram que as IES exercem o princípio de liberdade de flexibilidade delegada pelo Parecer 146/2002 para comporem suas ementas e respectivos conteúdos programáticos, conferindo-se uma maior autonomia na definição dos currículos plenos de seus cursos.

O cálculo do desvio padrão igual a 6 , também ratifica tal entendimento, no sentido de apontar para uma dispersão acentuada dos valores em relação à media aritmética.

Outra análise a ser considerada e de grande valia para o nosso entendimento é quanto às coincidências de adoção de conteúdo programático. Podemos observar que 7 das 8 IES pesquisadas, ou seja 87,5\% da amostra, valorizaram mais os conteúdos programáticos relacionados com os fundamentos da Administração e dos Processos Organizacionais (Planejamento, Organização, Direção e Controle), conforme podemos observar na Tabela 5, apresentando um dado importante, 65,90\% dos conteúdos programáticos adotados pelas IES estão relacionados com os itens já mencionados, ou seja teoria da administração, conforme podemos verificar na ementa da Faculdade Lions, Anexo 7.6, na qual consta: "Foco especial nas teorias, filosofias e funções da administração".

$\mathrm{Na}$ mesma tabela verificamos que os grupos de conteúdos 5 Administração da Qualidade para o Turismo, 7 - Formação e origem do conhecimento e 8 - Inserção do profissional de Turismo no mercado de trabalho, obtiveram respectivamente, apenas, 6, 2 e 4 conteúdos adotados por 3, 1 e 2 IES respectivamente. O que nos leva a inferir que as algumas IES incluem, nos seus currículos, conteúdos diversificados, com abordagens específicas que atendam a características regionais e necessidades mercadológicas atuais, conforme prevê a LDB e as diretrizes curriculares do curso de Turismo.

Com relação ao total de conteúdos verificados, podemos observar através da Tabela 4, que as IES pesquisadas adotaram 85 itens de conteúdo programático, 
sendo o que mais chama a atenção é a alta participação dos itens com menor adoção ou coincidência pelas IES, perfazendo um total de 81,18\% para os itens adotados 1, 2, 3 ou 4 vezes. Já os itens mais adotados, ou seja, 5, 6, ou 7 vezes, possuem uma participação quantitativa de apenas 16 conteúdos representando percentualmente apenas $18,82 \%$.

A partir dos resultados acima comentados, fica muito claro para 0 pesquisador que as IES, neste curto período de tempo não adequaram seus currículos aos parâmetros das Diretrizes Curriculares dos Cursos de Turismo, ainda apresentam muitas lacunas nos seus processos de flexibilização curricular. Entre estes, o fato de que os resultados tabulados ainda revelam que grande parte das ementas e programas analisados, bastante ricos em conteúdos, têm metodologia que, embora destaquem a importância da reflexão crítica dos conteúdos programáticos, podem conduzir a um tipo de aprendizagem de cunho meramente informativo, ainda distanciado daquela definida nas diretrizes Curriculares dos Cursos de Graduação em Turismo (p. 19) a qual, ainda, define o perfil, as competências e as habilidades que devem ser proporcionadas aos discentes do curso de Turismo.

Com relação às referências bibliográficas verificamos que apenas um título foi adotado por três IES como referencial teórico básico, o qual não é específico da atividade turística, mas sim, produzido para o curso de Administração de Empresas:

- MAXIMIANO, A. C. A. Introdução à Administração. São Paulo: Atlas, 1995.

Verificasse que a tendência acima relatada permanece na adoção da referência bibliográfica básica.

Para as referências bibliográficas complementares, verificamos também, que apenas um título foi adotado por quatro IES, o qual por sua vez é um livro específico da atividade turística:

- ACERENZA, Angel, Miguel. Administração do turismo. Bauru, SP: EDUSC, 2002.

Neste caso temos um livro generalista como referencial teórico básico e um livro especialista como referencial teórico complementar, mais adotados pelas IES 
pesquisadas, apresentando, no entendimento do pesquisador a tendência deveria ser o contrário, um referencial teórico básico produzido especificamente para a atividade turística e, como referenciais complementares, títulos generalistas utilizados por outras áreas com o objetivo de manter e estar sempre atualizado e acompanhando das constantes mudanças do conhecimento e do mercado.

Com relação às quantidades de referencial teórico básico e complementar adotado pelas IES, verificamos que não há um comportamento padrão, referendando a variável "flexibilização curricular" além de estar garantida a autonomia institucional, seja no todo pelas IES, seja especificamente pelos docentes que ministram a disciplina. Existe IES que adotou uma quantidade maior de referências bibliográficas básicas (UNIP $=23$ ) e uma quantidade bem menor de referencial bibliográfico complementar (UNIP $=9$ ).

O IESB adotou um padrão totalmente contrário ao exemplo acima, adotando 2 referências bibliográficas básicas e 22 referências bibliográficas complementares. Ressaltamos, ainda, os números da Faculdade Lions, onde foram adotadas 3 referências bibliográficas básicas e 6 complementares, mostrando, a nosso ver, mais coerência que as anteriores citadas como exemplo.

A média aritmética é utilizada com eficiência quando os dados que compõem o estudo tendem a ser homogêneos. Isso significa que não existem valores muito grande ou muito pequeno na série, conforme Tiboni (2003, p.104). É o caso do resultado dessa tabulação, tanto básica como complementar, a média não é um bom número para análise.

Mesmo assim inferimos que existe uma grande diversidade de livros adotados para atender à flexibilização dos conteúdos programáticos, embora persista a tendência para o enfoque de conteúdo na Administração.

O desvio padrão, como termômetro da dispersão dos dados, ratifica, exatamente o comentário do parágrafo anterior, no sentido de apresentar uma série de dados não homogêneos.

Um outro prisma para análise é o de estudar os dados de forma qualitativa, ou seja, quantas vezes o título foi adotado e verificar assim, as coincidências na adoção de livros pelas IES. As referências bibliográficas básicas apresentaram um resultado impressionante em termos de flexibilização e heterogeneidade, conforme apresentado na Tabela 9, onde 38\% (trinta e oito por cento) dos títulos foram adotados apenas uma vez e 60\% (sessenta por cento) foram adotados 
duas vezes. Considerando uma população de 8 IES pesquisadas, o grau de não coincidência é alto.

Praticamente o mesmo quadro se repete em relação às referências bibliográficas complementares, Tabela 10, apresentando $75 \%$ (setenta e cinco por cento) dos títulos adotados apenas uma vez e $21 \%$ (vinte e um por cento) dos títulos adotados duas vezes.

A Tabela 11 nos mostra que, dos 66 títulos adotados como referência bibliográfica básica, apenas 17 ou 25,76\% são livros específicos da atividade turística e 49 ou $74,24 \%$ do resultado são livros que não estabelecem o link com o turismo, são livros generalistas, voltados para a Administração de Empresas, situação alarmante em relação à proposta de formação já estudada.

E mais, quando analisamos os mesmos dados individualmente por IES, a situação passa a ser gravíssima, pois, existe instituição que não adota livros específicos da atividade turística para compor as referências bibliográficas básicas, ou seja, o discente recebe conceitos, técnicas, tendências da Administração, não direcionadas, traduzidas ou adaptadas para a atividade turística. Exemplificando: somente três IES, Faculdades Objetivo - Universidade Paulista - Faculdade Anhanguera, adotaram livros específicos da atividade turística nas referências bibliográficas básicas.

Para as referências bibliográficas complementares, verificamos uma situação mais amena, ou seja, dos 69 títulos adotados, 31 ou 44,93\% são livros específicos da atividade turística e 38 ou $55,07 \%$ são livros generalistas, que como mencionado, não apontam relação pertinente com o turismo.

Analisando o resultado por IES, individualmente, verificamos que também não há um comportamento padrão. Destacamos o IESB com 22 referências bibliográficas complementares, sendo que em 19 ou $86,36 \%$ verificamos uma precisa relação com a atividade turística.

O pesquisador está ciente de que não dá para julgar a qualidade e a eficácia da formação apenas pela bibliografia ou pelos conteúdos programáticos adotados. Entretanto, persiste a análise do pesquisador de que, embora não seja linear, há causalidade entre a seleção e incidência destes materiais pedagógicos e os modos de se articular e de se contribuir socialmente o conhecimento, a saber, como a disponibilização dos conhecimentos direciona as ações didáticas. 
6 - Considerações Finais

O cenário educativo revelado nesta pesquisa tem tempo e lugar. Foi realizada, por amostragem, em agências formadoras da Região Centro-Oeste, em um momento em que essas IES analisadas ainda se encontram em período de transição entre dois modelos de organização curricular.

A ênfase dada à Administração e suas ciências correlatas foram intencionais já que por sua inquestionável pertinência no processo formativo do profissional de Turismo, conceitos e práticas devem ter a sua importância consignada.

A pesquisa, tendo como eixo gerador o planejamento de ensino em Administração Aplicada ao Turismo, demonstrou o grau de dificuldade em que as IES ainda se deparam para compatibilizar seus currículos plenos às Diretrizes Curriculares, incluindo-se neste gerenciamento a questão motivadora deste trabalho, mencionada na Introdução: "a incógnita sem resposta".

Nesta perspectiva, a pesquisa foi realizada para a investigar dois dos problemas suscitados pelo desafio de promover uma formação de qualidade aos futuros profissionais do Turismo.

1 - Os conteúdos programáticos da disciplina de Administração ministradas nos cursos de turismo estão adequados às Diretrizes curriculares do curso de Turismo?

2 - Existe referencial bibliográfico específico da atividade turística que contemple o conteúdo programático da disciplina Administração Aplicada ao Turismo?

Realizou-se, inicialmente, um estudo bibliográfico para conhecer mais sobre a legislação, recomendações e pareceres sobre a formação de currículo dos cursos de graduação e, especificamente, do curso de turismo, visando um embasamento teórico consistente e atual. Verificou-se, também, a quantidade de IES que ministram cursos voltados para a atividade turística para análise e definição da amostra a ser pesquisada. De posse das ementas dos cursos de turismo, tabulou-se os dados referentes ao conteúdo programático e das referências bibliográficas básicas e complementares, o que subsidiou, após exaustiva análise, os comentários sobre os resultados obtidos.

Com relação ao primeiro problema, conclui-se que os conteúdos programáticos adotados estão adequados às Diretrizes Curriculares nos aspectos 
da flexibilização curricular e liberdade na elaboração de projetos pedagógicos, tendo em vista que os conteúdos programáticos analisados apresentam uma grande diversidade de itens, pouquíssimos comuns e muitos adotados apenas por uma IES.

Entretanto, permanecem lacunas em outros itens recomendados pelo CNE: quanto ao atendimento das demandas sociais, características regionais, aos avanços tecnológicos e mercadológicos e para adaptar-se em um ambiente de constantes mudanças, não foram contempladas fortemente, pois, poucas IES, apenas três, se preocuparam em disponibilizar materiais pedagógicos com esta vertente da formação profissional.

Neste sentido, nota-se que as IES ao utilizar uma "abertura" legal, a qual delegou autonomia para que elaborassem seus planejamentos pedagógicos, precisam entendê-la como o único de um processo de compatibilização de seus currículos a todas as recomendações das Diretrizes Curriculares para que esta autonomia não se configure uma arbitrariedade que leva ao isolamento, segmentação e estratificação da formação profissional.

Por outro lado, a legislação não previu a utilização desta "abertura" com responsabilidade para construir com pertinência e precisão a formação do discente, em relação às necessidades de conhecimento sólido que foque no perfil, habilidades e competências para exercer com profissionalismo a atividade turística.

Fica evidenciado nos dados analisados que as IES utilizaram as recomendações emanadas nas Diretrizes curriculares para a definição de seus projetos pedagógicos e respectivos conteúdos programáticos, porém, fica a ressalva acima.

A conclusão sobre o segundo problema demonstra que o processo de aperfeiçoamento curricular nas IES não se restringe a ultrapassar o momento de transição entre dois modelos de organização curricular: verificou-se que o referencial bibliográfico básico adotado, na sua maioria, não faz o link com a atividade turística: são títulos produzidos para outra área do conhecimento, como a Administração de Empresas e emprestados à atividade turística. Em conseqüência, a preocupação do pesquisador prende-se especialmente ao fato de como estes conteúdos extraídos de referencial bibliográfico direcionado para a 
generalidade estão sendo traduzidos ou adaptados para serem ministrados em sala de aula.

Verifica-se assim a relevância acadêmica em analisar criticamente os dados referentes à seleção e incidência do material bibliográfico adotado pelas IES já que estes suscitam novos questionamentos e nos remete à necessidade de outra pesquisa, agora centrada no processo ensino-aprendizagem praticado no cotidiano acadêmico.

Consideramos que os objetivos da pesquisa foram totalmente atingidos, no sentido de ter estudado exaustivamente os conteúdos programáticos das IES pesquisadas, comparando-os, verificando a relação entre eles, as coincidências entre a adoção de itens pelas IES, enfim, preparando um material teórico que será a base para o desenvolvimento de um texto que contemple todas ou pelo menos 90\% das necessidades de referencial teórico para a disciplina de Administração aplicada ao curso de Turismo.

Quanto às hipóteses levantadas, entendemos que não será possível uniformizar os currículos e ou conteúdos programáticos das IES, tendo em vista que a legislação atual já recebeu várias inovações que remetem os cursos de graduação para uma época de vanguarda, com conceitos atuais e preocupados com a formação adequada dos discentes em face da grande exigência de conhecimentos e habilidades que o mercado necessita de um profissional.

Uniformizar não, mas, também não se pode impedir ou cercear o trânsito ou transferência do discente de uma IES a outra. Diante do crescimento acelerado da oferta de cursos de Turismo em todo o país, a agências formadoras devem se tornar parceiras a fim de obter coerência mínima entre os diferentes cursos e entre as competências que se solicita para a formação do profissional em Turismo. Torna-se assim cada vez mais premente estabelecer o intercâmbio e a troca de idéias e experiências das IES entre si e com as demais entidades vinculadas à atividade turística. Além dos estudos técnicos, proporcionar condições para a pesquisa e estimular a participação em seminários, debates, conferências, atividades práticas, etc.

A outra hipótese levantada está relacionada com as quantidades de referencial bibliográficos básico e complementares adotados, se são suficientes para suportar o conteúdo programático dos cursos. Neste sentido, entendemos 
que quantitativamente sim, porém fica a ressalva já feita anteriormente sobre a necessidade de produção científica específica para a atividade turística.

Entendemos, que o caminho está traçado pelo poder público quando ele legisla sobre o assunto; pelo envolvimento das entidades de classes que atuam na atividade turística no momento em que se envolvem na elaboração de currículos mínimos para o curso de graduação em Turismo, pela competência de professores da Administração, um movimento conjugado no sentido de se distinguir a aprendizagem informacional de uma aprendizagem relacionada à experiência vivida.

Não podemos perder de vista, ainda, que a disciplina Administração Aplicada ao Turismo não visa a formação de Administradores. A partir dos subsídios disponibilizados pelos resultados desta pesquisa, aliados a outros estudos similares, as IES devem, gradativamente, atenuar esta tendência em prol da formação dos profissionais do Turismo.

Constatamos ainda, no curso desta pesquisa, que os cursos de bacharelado em Turismo, por suas características próprias e circunstanciais históricas, podem refletir com precisão a dupla perspectiva observada por Braga \& Calazans (2001. p. 47).

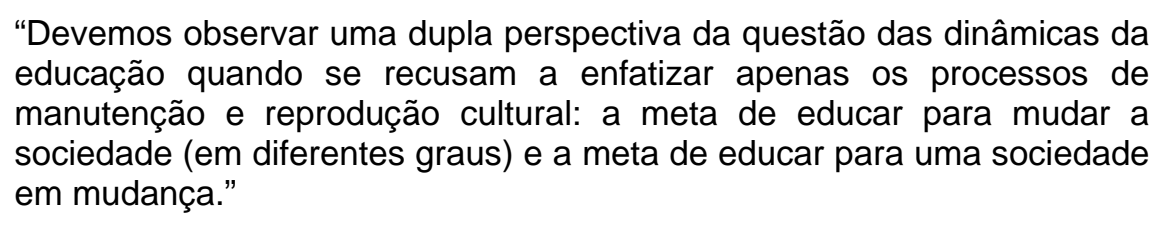

Finalmente, entendemos que deve haver uma grande sintonia entre o processo institucional de construção do currículo e o processo de formação, no sentido em que as Diretrizes deixem de ser a parte mais importante na formação.

O importante é o processo ensino-aprendizagem. 


\section{REFERÊNCIAS BIBLIOGRÁFICAS}

ANSARAH, Marília Gomes dos Reis. Formação e capacitação do profissional em turismo e hotelaria: reflexões e cadastro das instituições educacionais no Brasil. São Paulo : Aleph, 2002.

BRAGA, José Luiz, CALAZANS, Regina Zamith. Comunicação e Educação: questões delicadas na interface. São Paulo: Hacker, 2001.

DENCKER, Ada de Freitas Maneti. Pesquisa e interdisciplinaridade no ensino superior: uma experiência no curso de turismo. São Paulo: Aleph, 2002.

MATIAS, Marlene. Turismo Formação e Profissionalização. Barueri - SP : Editora Manole, 2002.

NISKIER, Arnaldo. LDB - A nova lei da educação : tudo sobre a lei de diretrizes e bases da educação nacional : uma visão crítica. Rio de Janeiro : Consultor, 1996.

RICHARDSON, Roberto Jarry. Pesquisa Social: métodos e técnicas. São Paulo Atlas, 1999.

VERGANA, Sylvia Constant. Projetos e Relatórios de Pesquisa em Administração. 4 ed. - São Paulo: Atlas, 2003.

TIBONI, Conceição Gentil Rebelo. Estatística básica para o curso de Turismo. 2 ed. - São Paulo: Atlas, 2003.

Sites:

www.embratur.gov.br

www.abbtur.com.br

IES pesquisadas de acordo com a Quadro 1

Outras fontes de pesquisa:

Manual de Monografia do CET 
ANEXOS 
ANEXO 1 - Ementa da Faculdades Objetivo e Universidade Paulista

INSTITUTO: Ciências Humanas

CURSO: Turismo SÉRIE: $3^{\circ}$ semestre TURNO: Noturno

DISCIPLINA: Administração Aplicada ao Turismo I

CARGA HORÁRIA SEMANAL: 2 h/a VALIDADE: 2003

\section{I - EMENTA}

Evolução histórica da administração. Conceitos básicos sobre administração e organização. Relação da Administração com as demais ciências sociais e suas aplicações nas empresas de serviços turísticos. Principais tendências da administração moderna para aplicabilidade nas empresas de turismo. Processos organizacionais e administrativos e as funções do administrador. A globalização e a gestão nas empresas. Políticas e procedimentos para organização, controle, direção. Competitividade no mercado: estudo de cluster.

\section{II - OBJETIVOS GERAIS}

1 - Conceituar as teorias de Administração;

2 - Estudar os princípios e as tendências da Administração.

III - OBJETIVOS ESPECÍFICOS

1 - Estudar os segmentos históricos que compõem o desenvolvimento das ciências administrativas;

2 - Conhecer os conceitos de administração e organização e as principais escolas administrativas.

3 - Orientar os alunos para o levantamento de dados e pesquisa em relação ao tema do Trabalho e Análise Interdisciplinar

IV - CONTEÚDO PROGRAMÁTICO

\section{$1^{\circ}$ Bimestre}

Evolução histórica da administração

Conceitos:

Administração 
Organização

Principais teorias administrativas

Taylor

Fayol

\section{$2^{\circ}$ Bimestre}

Tendências atuais da administração para aplicação nas empresas de turismo teorias de:

parceria,

terceirização,

reengenharia,

joint-ventur,

empowerment.

qualidade total,

incorporação

controle

franquia

A globalização e a gestão nas empresas.

Políticas e procedimentos para organização, controle, direção.

Competitividade no mercado: estudo de cluster.

Total Quality Control (TQC) e Auditorias.

Orientação para o tema do trabalho de análise Interdisciplinar.

V - ESTRATÉGIA DE TRABALHO

Aulas expositivas

Seminários

Leitura de textos e discussões

Visitas técnicas

Recursos audiovisuais utilizados:

- retroprojetor

- flip charter

- vídeo

- data-show 
VI - AVALIAÇÃO

Provas bimestral - 10,0

Seminário/trabalho - 10,0

Relatório de Visitas Técnicas - 10,0

Trabalho de Análise Interdisciplinar - 10,0

\section{VII - BIBLIOGRAFIA BÁSICA}

ALBRECHT, Karl. Programando o Futuro. São Paulo: Makron Books, 1994.

ALBRECHT, Karl . Revolução nos Serviços. São Paulo: Pioneira, 1992.

ANDRADE, Rui Otávio Bernardes de et al. Gestão ambiental - enfoque

estratgégico aplicado ao desenvolvimento sustentável. São Paulo : Makron

Books, 2.000

CAMPOS, Vicente Falconi. TQC - Controle de qualidade total. Rio de Janeiro: Block, 1992.

CAVASSA, César Ramirez. Hotéis - Gerenciamento, Segurança e

Manutenção. Trad. Cláudia Bruno Galvãn. São Paulo: Roca, 2001.

COBRA, Marcos. Administração: evolução, desafios, tendências. São Paulo:

Cobra, 2001.

FAYOL, H. Administração Industrial e Geral. São Paulo: Atlas, 1999.

MAXIMIANO, Antonio César Amaro. Teoria Geral da Administração: da escola científica à competitividade da economia global. $2^{\circ}$ ed. São Paulo: Atlas, 2000. MOTA, Fernando Peter. Teoria Geral da administração. São Paulo: Pioneira, 1999.

SANTOS, Milton. Por uma outra globalização do pensamento único à consciência universal. Rio de Janeiro: Record, 2001.

UHLMAN, Gunter Wilhelm. Administração: das teorias administrativas à administração aplicada e contemporânea. São Paulo: FTD, 1997.

WOOD, Thomaz Jr (Coord.). Gestão empresarial. São Paulo: Atlas, 2001.

VIII - BIBLIOGRAFIA COMPLEMENTAR

CHIAVENATO, Idelbrando. Introdução à administração geral. São Paulo: Atlas, 1980. 
KOONTZ \& O'DONNELL. Princípios de administração. São Paulo: Pioneira, 1970.

LERNER, Walter. Organização participativa: como a empresa brasileira pode enfrentar esse desafio. São Paulo: Nobel, 1991.

NAISBETT, John. Paradoxo global. São Paulo: Campus, 1994.

PETROCCI, Mário. Gestão de pólos turísticos. São Paulo: Futura, 2001.

THEOBALD, William F. (org.). Turismo Global. São Paulo: SENAC, 2001.

WALTON, Mary. O método Deming de Administração. Rio de Janeiro: Marques Saraiva, 1989.

BIBLIOGRAFIA REGIONAL

Cada campus deverá inserir a bibliografia local 
INSTITUTO: Ciências Humanas

CURSO: Turismo SÉRIE: $4^{\circ}$ semestre

TURNO: Noturno

DISCIPLINA: Administração Aplicada ao Turismo II

CARGA HORÁRIA SEMANAL: 2 h/a

VALIDADE: 2003

\section{I - EMENTA}

Administração e o mercado turístico. Gestão nos principais segmentos do mercado: Agência de Viagens, Meios de Hospedagem, Alimentos \& Bebidas, Transportadoras e empresas de Entretenimento e Eventos. "Cases". A disciplina contará com palestras para proporcionar a flexibilidade curricular.

\section{II - OBJETIVOS GERAIS}

Fazer a correlação administração e o mercado turístico.

Apresentar a gestão nos principais segmentos do mercado turístico

\section{III - OBJETIVOS ESPECÍFICOS}

Conhecer e analisar "cases" da gestão no mercado turístico.

1. Trazer profissionais dos vários segmentos turísticos para análise e discussão.

2. Orientar os alunos para o levantamento de dados e pesquisa em relação ao tema do Trabalho e Análise Interdisciplinar.

\section{IV - CONTEÚDO PROGRAMÁTICO}

$1^{\circ}$ Bimestre

A Administração atual no mercado turístico. "Cases":

parceria

terceirização

reengenharia

joint-venture

qualidade

gestão e Controle

franchising

reengenharia

competitividade 
Processos organizacionais e administrativos

Organização

Planejamento

Execução

Controle (Direção e Coordenação)

Função, do Administrador no mercado turístico

A gestão nos principais segmentos do mercado turístico:

agenciamento

meios de hospedagem

modais: rodoviário, ferroviário, aquaviário e aéreo

parques temáticos

empresas de eventos e recreação

consultoria

restaurantes

$2^{\circ}$ Bimestre

Gestão no poder público

Embratur

Secretarias Estaduais e Municipais

6 - Gestão de planos e projetos

7 - Gestão ambiental no mercado turístico

Eco-hotéis

8 - Gestão da qualidade em destinos turísticos

9 - Gestão de cluster: "Case" Caribe

10 - Orientação aos alunos com o tema do Trabalho de Análise Interdisciplinar.

V - ESTRATÉGIA DE TRABALHO

Aulas expositivas

Seminários

Leitura de textos e discussões

Visitas técnicas

Recursos audiovisuais utilizados:

- retroprojetor 
- flip charter

- vídeo

- data-show

VI - AVALIAÇÃO

Provas bimestral $-10,0$

Seminário/trabalho - 10,0

Relatório de Visitas Técnicas - 10,0

Trabalho de Análise Interdisciplinar - 10,0

VII - BIBLIOGRAFIA BÁSICA

ANDRADE, Rui Otávio Bernardes de et al. Gestão ambiental - enfoque estratgégico aplicado ao desenvolvimento sustentável. São Paulo : Makron Books, 2.000

BARROS, Claudius Dártagnan C. Excelência em serviços-questão de sobrevivência no mercado. São Paulo: Qualitymark, 1996.

CASTELLI, Geraldo. Turismo-atividade marcante. $4^{\circ}$ ed. Revisado e Ampliado. Caxias do Sul: EDUCS, 2001.

CAVASSA, César Ramirez. Hotéis - Gerenciamento, Segurança e Manutenção. Trad. Cláudia Bruno Galvãn. São Paulo: Roca, 2001.

COBRA, Marcos. Administração: evolução, desafios, tendências. $1^{\circ}$ ed. São Paulo: Cobra, 2001.

FLORES, Paulo Silas Ozores. Treinamento em qualidade. Fator de sucesso para desenvolvimento de hotelaria e turismo. São Paulo: Roca, 2002.

FITZSIMMONS, James ; FITZSIMMONS, Mona. Administração de serviços: operações, estratégia de marketing e tecnologia de informação. $2^{\circ}$ ed. São Paulo: Bookman, 2000.

FONSECA, Marcelo Traldi. Tecnologias gerenciais de restaurantes. São Paulo: SENAC, 2000.

GONÇALVES, Maria Helena B. Administração mercadológica. $2^{\circ}$ ed. São Paulo: SENAC, 2000.

LATTIN, Gerald W. Administración moderna de hoteles y moteles. México: Trillas, 1994. 
ROCHA, Cristobal Casanueva, JUNCO, Julio Garcia del e GONZALEZ, Francisco Javier Caro. Organización y gestión de empresas turísticas. Madrid: Pirámide, 2000.

SCHMENNER, Roger W. Trad. Lenker Peres. Administração de operações em serviços. São Paulo: Futura, 1999.

TEIXEIRA, Elder Lins. Gestão da qualidade em destinos turísticos. Rio de Janeiro: Qualitymark, 1999.

ZANELLA, Luiz Carlos. Administração de custos em hotelaria. $3^{\circ}$ ed. São Paulo: EDUCS, 2000.

WOOD JÚNIOR, Thomaz (coord). Gestão Empresarial: 8 propostas para o $3^{\circ}$ Milênio. São Paulo: Atlas, 2001.

\section{VI- BIBLIOGRAFIA COMPLEMENTAR}

ACERENZA, Angel, Miguel. Administración del turismo. México: Trillas, 1998. V1. ESTUDIOS y Perspectivas en turismo. 1992. Buenos Aires: CIET, abr. NAISBETT, John. Paradoxo global. São Paulo: Campus, 1997 PETROCCHI, Mário. Gestão de pólos turísticos. São Paulo: Futura, 2001. ULRICH, Dave et all. Liderança orientada para resultados. Como os líderes constroem empresas e aumentam a lucratividade. Trad. Afonso Celso da Cunha Serpa. Rio de janeiro: Campus, 2000.

\section{Periódicos:}

REVISTA Turismo em Análise. São Paulo: ECA/USP, n¹, v.1 e 2.

REVISTA Turismo em Análise. São Paulo: ECA/USP, n², V. 1 e 2.

REVISTA Turismo em Análise. São Paulo: ECA/USP, n.3, v.1 e 2.

REVISTA Turismo em Análise. 1993. São Paulo: ECA/USP, n. 4, v. 1 e 2. REVISTA Turismo em Análise. 1994. São Paulo: ECA/USP, n. 5, v. 1 e 2

\section{BIBLIOGRAFIA REGIONAL}

Cada campus deve inserir a bibliografia local. 
ANEXO 2 - Ementa da Faculdade Alves Faria

FACULDADES ALVES FARIA

PLANO DE CURSO

\author{
DISCIPLINA: \\ CURSO: \\ PROFESSOR(A): \\ CÓDIGO:
}

\author{
Administração I \\ Turismo \\ Ana Mônica Beltrão e Dobson Ferreira Borges \\ PERÍODO: PRE-REQUISITO: \\ $1^{\circ}$
}

\section{CARGA HORÁRIA: \\ 72 horas}

\section{EMENTA:}

Evolução histórica, história da administração, revolução industrial, princípios básicos de administração, princípios administrativos de Taylor, princípios de Henri Fayol, evolução da teoria administrativa; liderança; sistemas; planejamento; direção; controle; autoridade. hierarquia, análise e controle.

Processos da qualidade, fundamentos de marketing. gestão de recursos humanos. organização \& métodos, relação da administração com as demais ciências sociais e suas aplicações nas empresas de serviços turísticos (hotéis e demais meios de hospedagem, restaurantes e demais serviços de alimentação, empresas de eventos e lazer e agências e operadoras de turismo).

\section{JUSTIFICATIVA:}

O bacharel egresso do Curso Superior de Bacharelado em Turismo Ecológico e Hotelaria estará apto a planejar, vender e gerenciar projetos turísticos e hoteleiros. Do ponto de vista operacional ele será capaz de gerenciar departamentos do hotel ou restaurante, bem como etapas da organização e operacionalização de roteiros eco-turísticos. Ele será um profissional com visão crítica dos problemas do Brasil e de como eles interferem na questão da atividade económica do turismo, ao mesmo tempo em que estará preparado para as discussões e ações que interfaceam os empreendimentos turísticos. O programa do cursos propiciará ao egresso uma visão singular do eco-sistema brasileiro e as questões sociais e antropológicas que compõem esse ambiente permitindo-lhe portanto atuar criticamente em seu campo de trabalho.

\section{OBJETIVOS:}

1- Viabilizar a inserção dos futuros profissionais de Turismo e Hotelaria no mercado de trabalho local, regional, estadual e nacional, sobretudo, sob o viés do profissional empreendedor;

2- Possibilitar o treinamento dos futuros profissionais em situação real no meio turístico, nos meios de hospedagem convencidas com a IES e nos Laboratórios de Hospedagem e Alimentos e Bebidas;

3- Aquisição pêlos estagiários do conhecimento da realidade local, regional, estadual, nacional e de outros países quanto ao exercício da profissão, vivenciando-as nos vários campos e áreas de atuação;

4- Aplicação efetiva dos conhecimentos teóricos dos estágios à realidade do mercado, de forma a desenvolver suas aptidões para a atuação profissional, seja como elemento integrante do corpo técnico ou responsável nas entidades do direito público ou privado.

\section{CONTEÚDOS PROGRAMÁTICOS:}

\section{UNIDADE I: Fundamentos da Administração}

\section{1 - Evolução Histórica}

1.2 - 0 que é Administração, Habilidades, Papéis e Funções

1.3 - A administração Contemporânea e seus desafios

1.4 - Tendências da administração no Brasil e no mundo

1.5 - O que é Ética 
UNIDADE II: Teorias Administrativas

2.1 - Da Escola Clássica aos novos modelos de administração

2.2 - História e conceitos

UNIDADE III: $O$ ambiente de negócios

3.1-0 ambiente externo

3.2 - Ambiente interno

3.3 - Por que as organizações são necessárias?

3.4 - As funções da Empresa

3.5 - Níveis Hierárquicos da Empresa

UNIDADE IV: Organização

4.1 - Definição (organização formal e organização informal )

4.2 - Divisão do trabalho

4.3 - Modelos de estrutura organizacional

4.4 - Desenho de cargos e tarefas

4.5 - Delegação de Autoridade e Empowerment

UNIDADE V: Direção e Controle

5.1 - A função de direção e os níveis hierárquicos

5.2 - Administração participativa.

5.3 - Motivação Humana

5.4 - Liderança

5.5 - Comunicação

5.6 - Sistemas de Administração

5.7 - Processo de Controle

UNIDADE VI: Planejamento

6. 1 - Estratégia Empresarial

6.2 - Missão, Objetivos e Política

6.3 - Planejamento e os seus níveis

6.4 - Tomada de decisão

UNIDADE VII: Formação e origem do Conhecimento

7.1-0 emprego na Era do Conhecimento

7.2 - O executivo para o novo cenário

UNIDADE VIII: Inserção do profissional de Turismo e Hotelaria no mercado de trabalho
8.1- Mercado de trabalho
8.2 - Papel do profissional
8.3 - Perspectiva

\section{AVALIAÇÃO:}

Metodologia de ensino consistirá de preleções, com auxílio de recursos audiovisuais, discussões de estudo de casos e estudos dirigidos, elaboração de trabalhos de pesquisa bibliográfica e de pesquisa de campo. Será seguido os seguintes procedimentos didáticos: Aulas expositivas e dialogadas; Estudos dirigidos; Debates; Trabalhos individuais e em grupos;

Observação da participação dos alunos na aula, questões orais aleatórias, resolução de exercícios, provas diversas (escrita, oral, prática, em duplas, grupos ou individuais, com consulta e sem consulta).

Avaliação será composta de N 1, N2 e N3 sendo: 
$\mathrm{N} 1$ => 70\% (setenta por cento) do valor da avaliação, será uma prova escrita formal e os 30\% (trinta por cento) restantes de atividades desenvolvidas em sala de aula como observação da participação do aluno na aula, comportamento, frequência, resolução de exercícios, seminário, visita técnica.

N2 => 70\% (setenta por cento) do valor da avaliação, será uma prova escrita formal e os $30 \%$ (trinta por cento) restantes de atividades desenvolvidas em sala de aula como observação da participação do aluno na aula, comportamento, frequência, resolução de exercícios, seminário, visita técnica.

N3 => prova escrita formal, com todo conteúdo visto no semestre, valendo 100\% (cem por cento).

\section{BIBLIOGRAFIA:}

\section{Básica}

MORAES, Arma Maris Pereira, Iniciação ao Estudo da Administração, São Paulo, Makron Books, 2000

Livros Complementares:

MAXIMIANO, António César Amam, Introdução à Administração 5' edição. São Paulo, Atlas, 1999.

MONTANA, Patrick, Administração,, $\quad$ São $\quad$ Paulo, $\quad$ Saraiva, 1998 OLIVEIRA, Djalma de Pinho Rebouças, Sistemas, Organização \& Métodos, $10^{a}$ edição. São Paulo, Atlas, 2000

-ROOS, Daniel, e outros, A Máquina que mudou o mundo. Rio de Janeiro, Editora Campus. TAYLOR, Frederick W., Princípios de Administração Científica. São Paulo, Editora Atlas ACKOFF, R.L. Planejamento Empresarial. Rio de Janeiro: Livros Técnicos e Científicos, 1975

ALBRECHT, Karl. Programando o Futuro. São Paulo, Makron Books, 1994. . Revolução nos Serviços. São Paulo, Pioneira, 1992.

BARROS, Claudius Dártagnan C. Excelência em serviços - questão de sobrevivência no mercado. São Paulo, Qualitymark.

NAISBETT, John. Paradoxo global. São Paulo, Campus. 
ANEXO 3 - Ementa da Faculdade Cambury

\section{Programa da Disciplina}

CGE. 02

Revisão: 00

\section{CAMBURY}

Curso: Turismo

Disciplina: Introdução a Administração

Docente Responsável: Aldo Eurípedes

Soares de Oliveira
Habilitação: Bacharel em Turismo

Carga Horária: 36 hs/A

Turma/ Período: 2003-2/3

\section{EMENTA:}

Visão histórica e enfoque das funções administrativas como Planejamento, Organização, Direcao e Controle; motivação; liderana; criatividade dentro das organizações

\section{OBJETIVOS:}

Capacitar os alunos para o conhecimento das principais teorias de Administração, sua evolução histórica bem como conceitos e o Processo Administratifvo. Ampliar os concheei mentos sobre a organização

\section{CONTEÚDO PROGRAMÁTICO:}

Unidade I

- Principais Teorias Influenciadoras do Pensamento Administrativo;

- Estrutura organizacional;

- O presente e as perspectivas futuras da Administração.

Unidade II

- O Administrador;

- O processo de Administração;

- O Papel e as habilidades do Administrador.

Unidade III

- Planejamento

- Elementos essenciais;

- Técnicas para tomada de decisão.

Unidade IV

- Organização

- Projeto de cargos;

- departamentalizaçâo.

Unidade $\mathrm{V}$

- Direcao

- Liderança;

- Motivação;

- Comunicação.

Unidade VI

- Controle

- Estratégias de controle;

- Etapas do processo de controle.

\section{BIBLIOGRAFIA BÁSICA: ( OBEDECER NORMAS ABNT )}

DUBRIN, Andrew J.- Princípios de Administração. Rio de Janeiro. LTC, 1999 MEGGINSON, Leon Donafd Mosley \& JR. Paul Petri - Adminstração - Conceitos Aplicações. São Paulo. Harbra, 1998

MONTANA, Patrick J. \&CHARNOV, Bruce H. -Administração. São Paulo. Saraiva, 1999 
BIBLIOGRAFIA COMPLEMENTAR: ( OBEDECER NORMAS ABNT )

MASIERO, Gilmar- Introdução à Administração. São Paulo. Atlas, 1998.

CHIAVENATO, Idalberto - Introdução à Teoria Geral da Administração. Sãp^Paulo. Campus,2001.

Drucker, Peter F. - Introdução a Administração, São Payto' Ed. Atlas, 1995 MORAES, Anna Maris Pereira de - Iniciação ao Estudada Administração. São Paulo. Makron Books, 2000. 
ANEXO 4 - Ementa da Faculdade Anhanguera

Administração de Empresas de Turismo I

Ementa: Fundamentos da Administração. Análise das organizações. Organização. Planejamento. Direção. As funções administrativas. Sistemas organizacionais. Processos, desempenho e estratégias organizacionais. Gestão organizacional frente aos novos paradigmas.

Bibliografia Básica:

BOTELHO, E. Administração inteligente: A revolução Administrativa. São Paulo: Atlas, 1996.

CERTO, S C Peter, J.P. Administração estratégica. São Paulo: Makron, 1993. CHIAVENATO, I. Vamos abrir um negócio. São Paulo: Makron, 1995.

Bibliografia Complementar:

DRUCKER, P. F. Administração de organizações. São Paulo: Pioneira, 1994. A nova era da Administração. São Paulo: Pioneira, 1989.

GALBRAITH, J. K. Organizando para competir no futuro. São Paulo: Makrom, 1995.

RAIMUNDO, P. R. O que é administração: A análise integrada das organizações. São Paulo: Atlas, 1993.

TAPSCOTT, D. Mudança de paradigma. São Paulo: Makron, 1995.

Administração de Empresas de Turismo II

Ementa: Administração aplicada às empresas turísticas. O contexto: serviços e turismo. O ambiente organizacional. Da microempresa à transacional de turismo. Análise dos tipos de prioridades, formas de organização e porte das empresas. Novas estratégias e política para as empresas de turismo.

Bibliografia básica:

GALBRAITH, J. K. Organizando para competir no futuro. São Paulo: Makron, 1995. 
LONGNEKER, J. G. et alii. Administração de pequenas empresas. São Paulo: Makron, 1997

ACERRENZA, Miguel Angel. Administração do turismo. Edusc, 2002.

Bibliografia complementar:

TRIGO, Luis Gonzaga G. A sociedade pós-industrial e o profissional em turismo. Campinas: Papirus, 1998.

. Turismo e qualidade: Tendências contemporâneas. 5 ed.

Campinas: Papirus, 1999.

AZEVEDO, João $H$ de. Como iniciar uma empresa de sucesso. São Paulo: Qualitymark, 1996.

BOTELHO, E. Administração inteligente a: A revolução dministrativa. São Paulo: Atlas, 1996. 
ANEXO 5 - Ementa do Instituto de Ensino Superior de Brasília

\section{DISCIPLINA: ADMINISTRAÇÃO EM EMPRESAS DE TURISMO}

CARGA HORÁRIA: 72 horas/aulas

PERÍODO: Noturno - 1\%/2003

SEMESTRE: $2^{\circ}$ Semestre CRÉDITOS:

PROFESSOR:

RICARDO Da SILVA

CURSO DE TURISMO

\section{EMENTA}

O Curso visa oferecer um conjunto de conceitos e princípios básicos que fundamentam o estudo e análise das relações estruturais e organizacionais das Empresas de Turismo.

O objetivo é conduzir o aprendizado do aluno ao conhecimento das estruturas administrativas empresariais e públicas, direcionado ao estudo do mercado turístico. Ao mesmo tempo oferecer ao aluno a oportunidade para a percepção das atividades administrativas que se processam internamente no âmbito organizacional, ou seja, fornecer conhecimento necessário à implantação nas Empresas de Turismo de uma estruturação, controle, planejamento e qualidade. Visa portanto, a conscientização dos participantes sobre a importância dos elementos administrativos como chave de uma estratégia empresarial.

Portanto, habilitar os participantes a uma visão técnica de gestão empresarial e sua aplicabilidade no setor Turístico e capacitar os mesmos a uma visão crítica das características de mercado e agir como agente indutor das transformações sociais.

\section{CONTEÚDO PROGRAMÁTICO}

1. Apresentação do Programa e discussão sobre os procedimentos do curso.

2. Características da Administração aplicada ao Setor Turístico.

3. Conceitos básicos de administração organizacional.

4. Análise dos tipos de escolas de Administração: a) Abordagens clássicas,

b) Abordagens contemporâneas e c) Perspectivas para o futuro da administração.

5. Macroambiente Administrativo: econômico, tecnológico, demográfico e ambiental.

6. Ambientes competitivos: concorrentes, entrantes, substitutos, fornecedores e consumidores. 
7. Modelos gerenciais ; parceria, terceirização, reengenharia, joint-ventures, qualidade e controle.

8. Visão dos programas de TQM e JIT : histórico e fundamentos.

9. Definição e termos utilizados na tipologia turísticas para a qualidade.

10. Análise do processo Organizacional e Administrativo.

11. Ética e responsabilidade Empresarial.

12. Turismo e Sociedades Contemporâneas. O TurisBusiness.

13. Mudanças de Paradigmas em Gestões Administrativas; vantagens, obstáculos e repercussões nas Organizações.

14. Abordagem estratégica das empresas. Formas de dimensionamento, valorização e competitividade.

15. Oportunidades de negócios. Projeção no desenvolvimento econômico.

16. Transformação de Conhecimento em Negócio. Processos de transferência de competências.

17. Funções do Administrador nas Empresas de Turismo.

Metodologia de Ensino

O procedimento de ensino do curso será na base de exposições feitas pelo professor, bem como de leituras sugeridas para discussão em classe, apresentação de seminários e avaliação de participação dos alunos.

Os alunos deverão ler o que Ihes for sugerido previamente, pois assim estarão preparados para participar das análises dos temas.

Os mesmos devem participar de forma crítica e questionar as idéias que lhes forem apresentadas sob diversos pontos de vista, com o objetivo de compreender a problemática das questões.

Espera-se que todos atendam todas as aulas e sejam participantes ativos do processo ensino-aprendizagem.

\section{AVALIAÇÃO}

A avaliação do desempenho dos alunos será feita através dos seguintes itens:

Participação e Contribuição nas discussões em classe ( 10\%)

Desempenho no grupo e nos seminários (10\%)

Exposição oral sobre o tema tratado (20\%)

Provas bimestrais com, no máximo, dez questões (60\%) 
BIBLIOGRÁFIA BÁSICA

BERNARDES,C.; MARCONDES,R.C., Teoria Geral da Administração: gerenciando organizações. São Paulo: Saraviva, 2003.

MAXIMIANO, A. C. A. Introdução à Administração. São Paulo: Atlas, 1995.

\section{BIBLIOGRAFIA COMPLEMENTAR}

ACERENZA, M. A. Administración del Turismo, Vol. I. e Il. México: Trillas, 1997.

ALFONSO, E. \& DÍAZ, H. Planificacion Turística: Un Enfoque Metodológico. México:

Trillas, 1982

ANDRADE, J. V. Turismo: Fundamentos e Dimensões. São Paulo: Ed. Ática, 1998.

ANSARAH, M. G. R. Turismo - O que você precisa saber para investir no setor. São Paulo:

SEBRAE, 1996.

ANSARAH, M. G. R.(Org.) Turismo: segmentação de mercado. São Paulo: Futura, 1999.

BARRETO, M. B. Planejamento e Organização em Turismo. Campinas, SP: Papirus, 1991.

BENI, M. C. Análise Estrutural do Turismo. São Paulo: Ed. SENAC, 1997.

DENCKER, A. F. M. Métodos e Técnicas de Pesquisa em Turismo. São Paulo: Futura, 1998.

DRUCKER, P. Introdução à Administração. São Paulo: Pioneira, 1998.

CAVASSA, C. R. Gestion Administrativa para Empresas Turísticas. México: Trillas, 1993.

GASTAL, S. et.al. Turismo: 9 Propostas para um saber-fazer. s/c: Edição dos Autores, 1998.

IGNARRA, L. R. Fundamentos do Turismo. São Paulo: Pioneira, 1999.

LAGE, B. H.G. \& MILONE, P. C. Turismo: teoria e prática. São Paulo: Ed. Atlas, 2000.

O.M.T. - Organización Mundial del Turismo. Lo que Todo Gestor Turistico Debe Saber. Madrid:

OMT, 1997.

PETROCCHI, M. Turismo, Planejamento e Gestão. São Paulo: Futura, 1998.

RODRIGUES, A.B. (Org.) Turismo e desenvolvimento Local. São Paulo: Ed. Hucitec, 1997.

RUSCHMANN, D. van de M. Turismo e Planejamento Sustentável: A proteção do Meio

Ambiente. Campinas, SP: Papirus, 1997.

TABARES, F. C. Comercialización del Turismo. México: Trillas, 1990. 
TRIGO, L. G.G. A Sociedade Pós-Industrial e o Profissional em Turismo. Campinas, SP: Papirus,

1998.

. Turismo Básico. São Paulo: Ed. SENAC, 1998.

_. Turismo e Qualidade : Tendências contemporâneas. Campinas, SP:

Papirus, 1993

STONER, J. A. F.\& FREEMAN, R.E. Administração. Rio de Janeiro: Prentice-Hall, 1985.

mini currículo

Bacharel em Economia - Universidade de São Paulo - USP

Mestre em Economia - Universidade Federal do Rio de Janeiro - UFRJ

Mestre em Administração - Universidade de Brasília - UnB

Doutorando em Administração Empresarial - Université de Sorbonne I - Paris

Professor Visitante da UnB - Dept. de Administração. 
ANEXO 6 - Ementa da Faculdade Lions

\section{FACULDADE LIONS}

Fundação Educacional de Goiás

CURSO: TURISMO

Disciplina: Introdução à Administração

Professor: Arédio Teixeira Duarte

Período

Segundo

Pré-requisito

Não tem
Créditos

04
Carga Horária

60 horas

Semestre letivo

$2002 / 2$

\section{EMENTA}

Visão geral dos princípios e práticas relevantes da administração aplicada às organizações contemporâneas. Foco especial nas teorias, filosofias e funções da administração. Organização, planejamento e direção: comunicação, tomada de decisão, poder e autoridade. Ênfase na utilização das informações de custo, nas tomadas de decisões internas do empreendimento. Análise de custos, controle, alocação de recursos e planejamento. Sistemas organizacionais e relações interorganizacionais e de ambiente.

\section{OBJETIVOS}

\subsection{GERAL:}

Capacitar o aluno para compreender a natureza dos encargos e propósitos fundamentais da administração e sua importância no contexto das realizações humanas; proporcionar-Ihe capacitação para identificar o campo, o objetivo e os conteúdos essenciais ao estudo das organizações; possibilitar-lhe uma visão panorâmica do processo de evolução, estado atual do conhecimento da administração e percepção de sua complexidade.

\subsection{ESPECÍFICOS:}

a) Capacitar o aluno tanto de forma teórica como prática, apresentando conteúdo informativo e instrucional; 
b) Dar ao aluno uma visão globalizante e genérica do assunto, de modo que possa assimilar de forma integrada todo o processo de desenvolvimento administrativo e organizacional dos empreendimentos, destacando as consequências sociais oriundas desse processo;

c) Focalizar a importância da Administração na condução do trabalho organizado, realçando sua evolução histórica como ciência;

d) Abordar o macroambiente e suas implicações no desenvolvimento administrativo, de forma a penetrar no mundo das organizações modernas, enfocando seus objetivos, as formas de propriedades dos recursos, expansão e propriedade;

e) Enfatizar o ambiente organizacional interno, destacando as diferentes áreas funcionais e os diversos subsistemas;

\section{PROGRAMA}

I. A Administração e as funções do administrador

a) Atividades interpessoais;

b) Outros papéis do administrador: processamento de informações e papéis de decisão;

c) Níveis hierárquicos e competências gerenciais.

II. As teorias da Administração:

a) Escola Clássica

Teoria da Administração Científica

Teoria Clássica

Teoria da Burocracia

b) Teoria das Relações Humanas

c) Teoria Comportamental

d) Enfoque Sistêmico

e) Teoria da Contingência

III. O processo de planejamento:

a) Noções gerais de planejamento;

b) Planejamento estratégico;

c) Planejamento gerencial; 
d) Ferramentas de planejamento e de tomadas de decisão.

IV. O processo de organização:

a) Noções gerais de organização;

b) Modelos organizacionais;

c) Estrutura organizacional;

d) Dinâmica organizacional, mudanças e inovações.

V. O processo de direção:

a) Noções gerais de direção;

b) Motivação desempenho e satisfação;

c) Liderança e dinâmica de grupo;

d) Comunicação e negociação.

VI. O processo de controle:

a) Noções gerais de controle;

b) O controle eficaz;

c) O controle operacional;

d) Sistemas de informações gerenciais.

\section{METODOLOGIA}

Os conteúdos programáticos serão abordados mediante aulas expositivas dialogadas, fundadas no requisito de participação ativa dos alunos, pressupondose leitura prévia orientada e preparação de esquemas e/ou resumos dos temas estudados. As dificuldades serão trabalhadas durante os debates. Como procedimento complementar poder-se-á adotar estudo em grupos e seminários.

\section{AVALIAÇÃO}

I. A avaliação do aluno incide sobre a frequência e o aproveitamento.

II. A frequência mínima para aprovação é de $75 \%$ (setenta e cinco por cento) das aulas e atividades.

III. A avaliação será expressa em graus de zero a dez, computados até a primeira casa decimal, excluindo-se os arredondamentos. 
IV. Medida de aproveitamento: média das notas de provas, trabalhos, exercícios, projetos, relatórios e demais atividades programadas.

V. Critérios de aprovação:

a) Sem o exame final: média de aproveitamento não inferior a 7.0 (sete), antes do exame final;

b) Com exame final: quando a média de aproveitamento, inferior a 7,0 (sete inteiros) e não inferior a 3,0 (três inteiros), somada à nota do exame final, levar a uma média 5,0 (cinco inteiros) ou maior, através de operação de média simples.

\section{BIBLIOGRAFIA}

BIBLIOGRAFIA BÁSICA

MAXIMIANO, António Cezar Amaru, Introdução à Administração, 4a . ed. São Paulo, Atlas, 1995.

CHIAVENATO, Idalberto, Administração - Teoria, Processo e Prática, $3^{a}$. ed. São Paulo, MakronBooks, 1991.

DRUCKER, Peter, Introdução à Administração, 3ª ed. São Paulo, Pioneira, 1977.

\section{BIBLIOGRAFIA COMPLEMENTAR}

STONNER, James A. F. \& FREEMAN, R. Edward, Administração, 5a. ed. Rio de Janeiro. Prentice Hall do Brasil Lida. 1995.

ACERENZA, Miguel, Administratión dei Turismo. México, Trilias, 1977, V. I e 2

FERREIRA, A. \& REIS, A. Gestão Empresarial: de Taylor aos Nossos Dias. São Paulo. Pioneira, 1992.

PINTO, Miguel, Fundamentos da Administração no Turismo. Rio de Janeiro. Infobook, 2000.

LODI, João Bosco, História da Administração, 3ª . ed. São Paulo, Pioneira, 1983.

CHIAVENATO, Idalberto, Administração de Empresas - uma Abordagem Contingencial. 4ª . ed., São Paulo, Makron Books, 1991. 
ANEXO 7 - Ementa do Instituto de Ensino Superior de Cuiabá

\section{$4^{\circ}$ SEM}

Administração

\section{Conteúdo Programático:}

Fundamentos da administração. Análise das organizações. As funções administrativas. Organizações e recursos humanos. Planejamento científico. Organização administrativa. Desenvolvimento e organização. Objetivos da organização. Grupo e organização. Organização dos objetivos.

Bibliografia:

- FERREIRA, A. A. Gestão Empresarial: de Taylor aos Nossos Dias. SP. Pioneira, 1997.

- KWASNICKA, Eunice Lacava. Introdução à Administração. São Paulo: Atlas, 1995

- MAXIMIANO, Antônio Cesar Amarú. Introdução à Administração. SP. Atlas, 1995.

- MONTANA, Patrick J. Administração. São Paulo: Saraiva, 1998.

- PARK, Kil Hyang. Introdução ao Estudo da Administração. São Paulo: Pioneira, 1997. 